$$
\text { عنوان الدراسة }
$$

فعالية استخدام تقييم البورتفوليو "Assessment Portfolio " في تنمية الابتكار لدي أطفال

$$
\text { الروضة " }
$$

$$
\text { مدرس بقسم رياض الأطفال - كلية التربية النوعية }
$$


مثكلة الدراسة :

تحددت مشكلة الدراسة من خلال ندرة البحوث التي ربطت بين فاعلية التقويم خاصة أسلوب تقييم

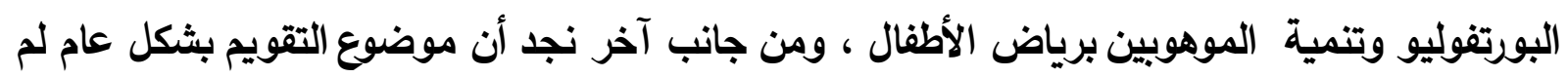

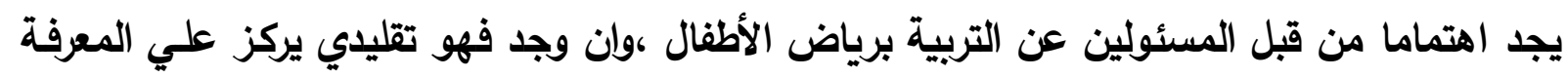

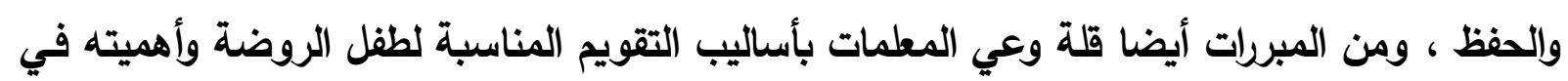

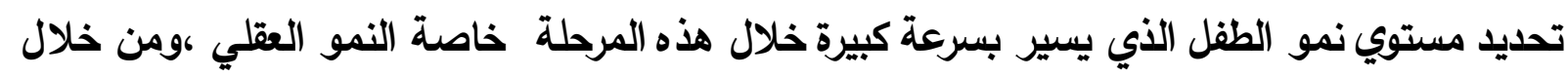

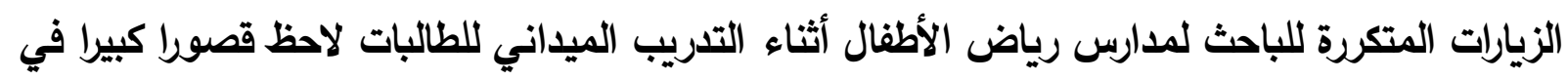

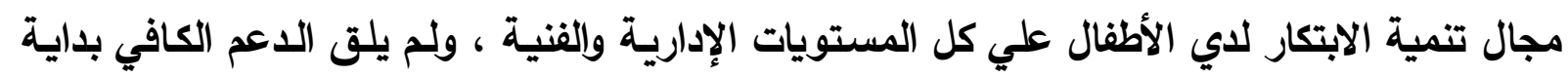

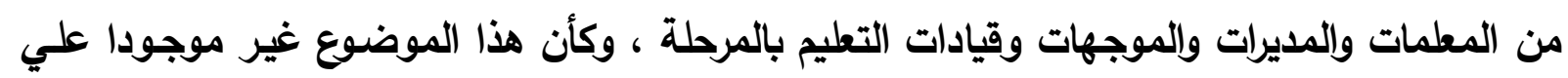

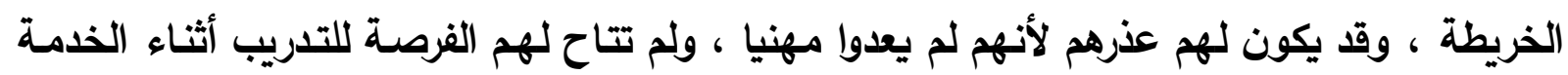

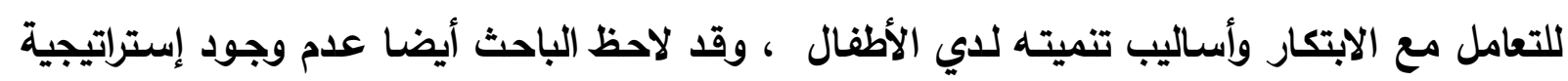

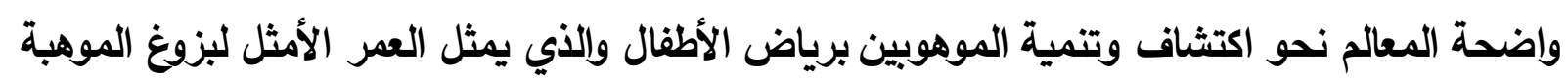

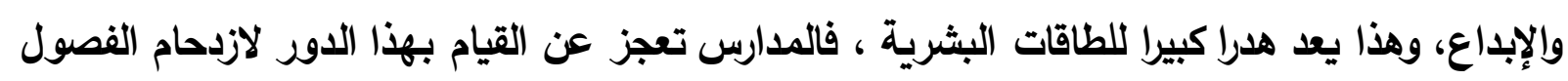

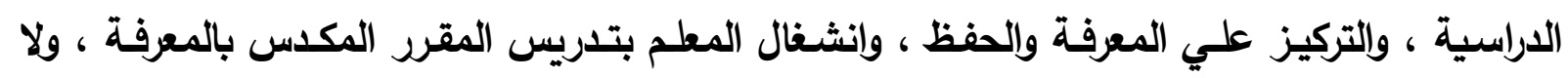

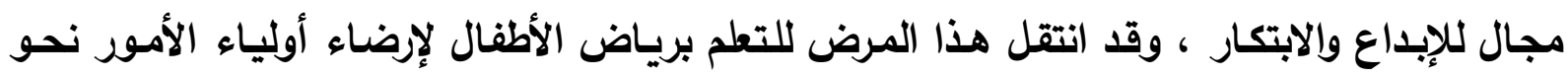

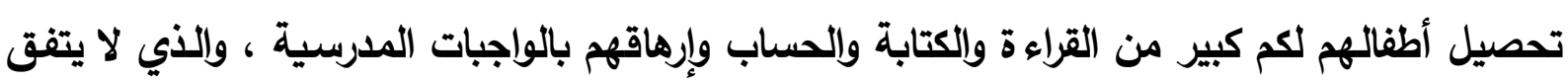

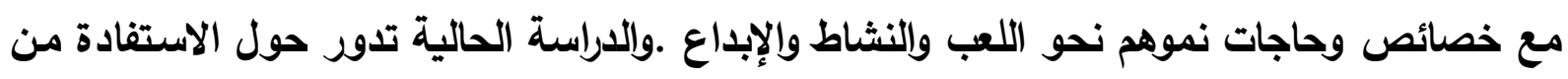

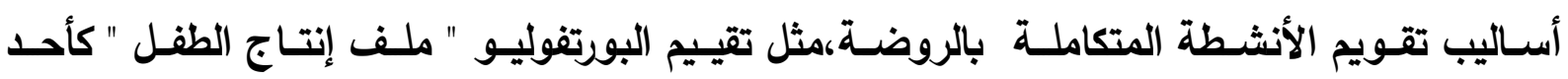
الاتجاهات المعاصرة في مجال تقييم الطفل تكون صادقة وثابتة ، يمكن الاعتماد عليها لتنمية الابتكار

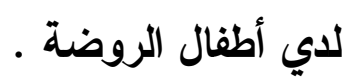

من العرض السابق يمكن صياغة مشكلة الدراسة في التساؤلات الآتية :

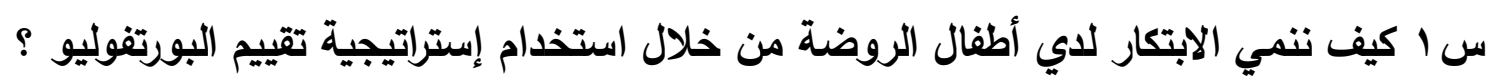

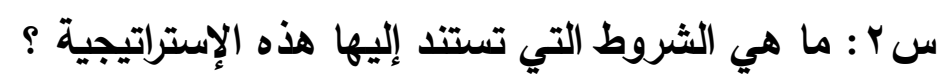

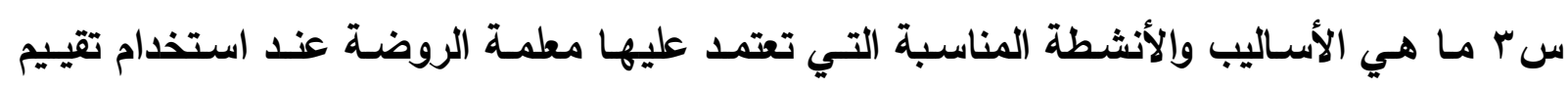
البورتفوليو ؟

س ؛ ما مدي تأثير هذه الأساليب والأنثطة التقويمية علي تنمية الابتكار لاي أطفال الروضة ؟ ؟

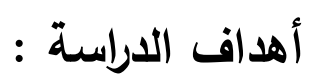

1 - استخدام أسلوب تقييم البورتفوليو للحم علي المستوي الفعل لجميع جوانب نمو الأطفال . 
r - الاعتماد علي هذا الأسلوب كأداة مناسبة لتنمية الابتكار لاي أطفال الروضة. r - التحقق من فعالية هذه الأنثطة التقويمية على تنمية الابتكار لدي أطفال الروضة.

أهمية الدراسة :

أولا : الأهمية النظرية:

- - تتناول مرحلة الطفولة المبكرة والتي تمثل أهم مرحلة عمرية في حياة الإنسان ، والتي تثكل

مفاهيمه واتجاهاته الأساسية التي تبلور شخصيته في المستقبل .

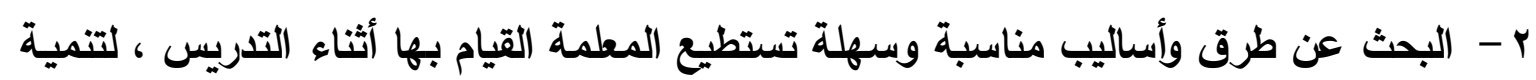

الابتكار لاي أطفالها في الصغر من مالب مناسبه وسن

ثانيا : الأهمية التطبيقية :

1 - تعميم استخدام تقييم البورتفوليو برياض الأطفال ، كاداه للحكم علي جوانب نمو الطفل ،

ومواكبة الاتجاهات العالمية في هذا المجال .

r - قد تستفيد وزارة التعليم والإدارات التعليمية في مجال إعداد برامج تدريبية لمعلمات وموجهي

رياض الأطفال علي كيفية استخدام تقييم البورتفوليو.

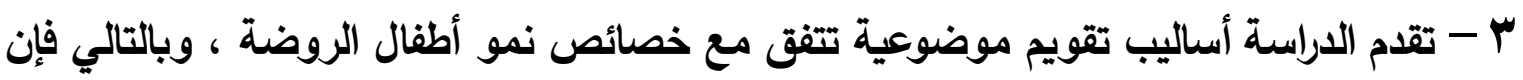

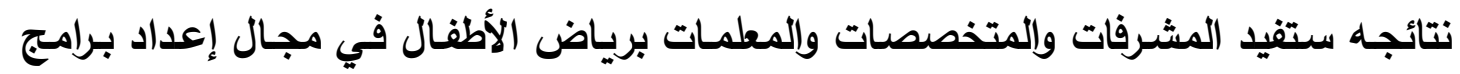

تقويمية للأنثطة اليومية بما ينعكس على تنمية الابتكار وتطوير العمل برياض الأطفال.

: مصطلحات الدراسة :

1 - فعالية : فعالية أي فرد لأي مجال يتحدد بمدي قدرة هذا الفرد علي تحقيق الأهداف المرجوة .

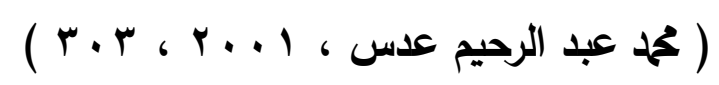

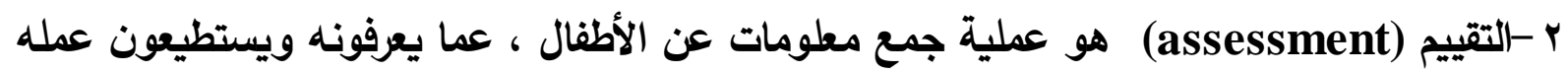

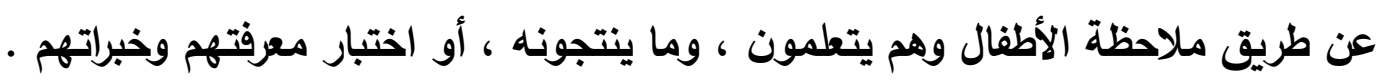

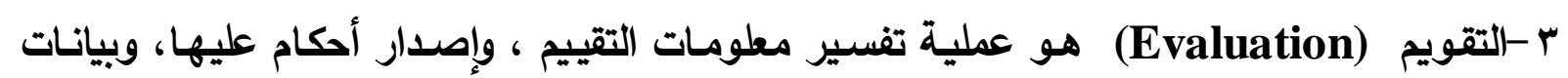
التقييم تعكس ما يجري في حجرة الدراسة ، وتصبح ذات معني حينما نقرر فحسب أنها تعكس شيئا

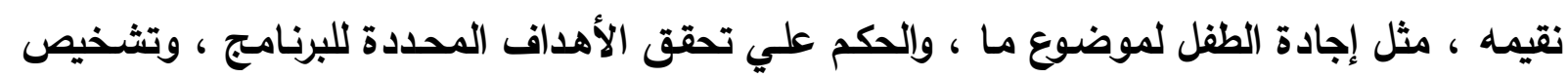

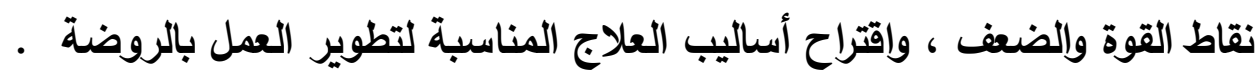
؛ -الاختبار (TEST) هو وسيلة للتقييم بمعني انه أداة قياس تستخدم لتوثيق تعلم الأطفال .

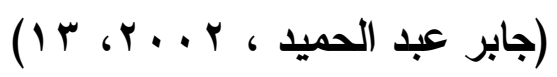




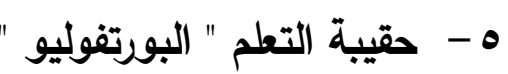

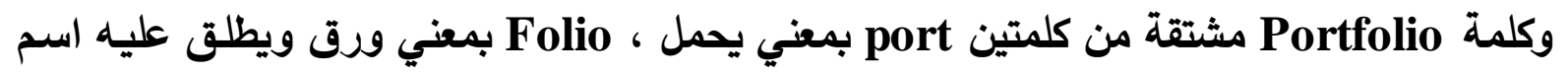

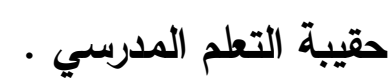
وهي حقيبة للمتطم تحتوي علي مجموعة من المقتنيات التي تخبرنا عن جهود الطفل وتقدمه وتحصيله

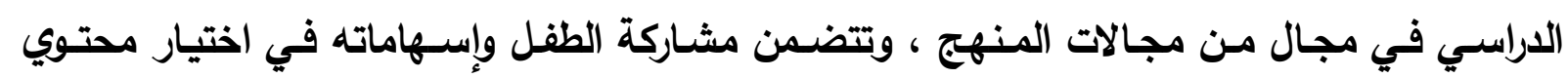
(Arter And Other 1992) الحقيبة ، والإرشادات ومعايير الحكم علي العمل ، والتأملات الذاتية للطفل . ومن تحليل التعرف السابق نجد أن الطفل يثارك بفاعلية مـع المطلمة في إعداد الدقيبة ، وتثمل

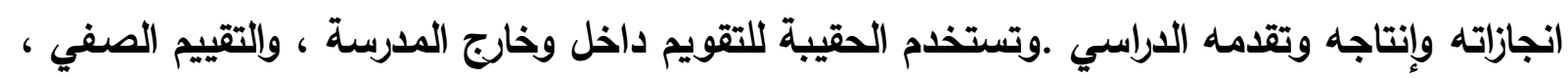

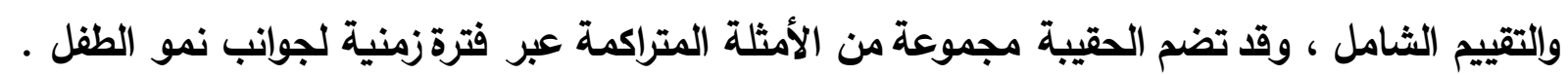

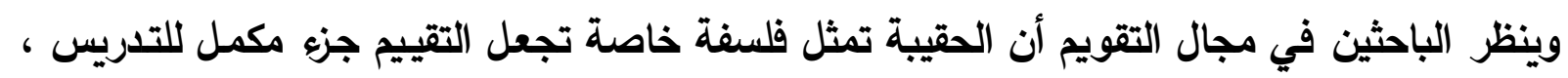

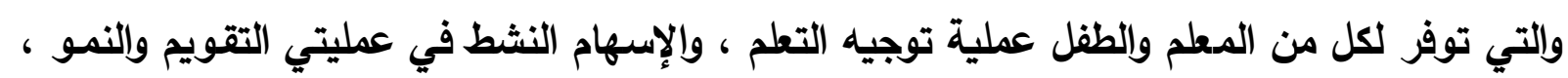

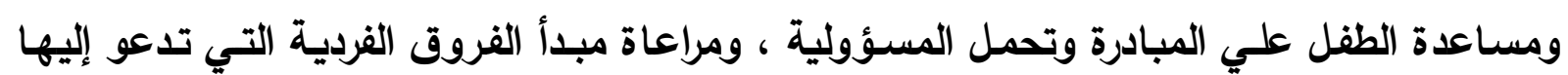
التربية الحديثة . ومدة الطفل عل

צ - إنتاج الأطفال : يعد إنتاج الطفل من المؤشرات الهامة لاكتثاف موهبته والذي يثمل جوانب متعددة أكاديمية أو فنية مثل كتابة قصة ، شعر ، تجارب علمية ، ابتكار في الرسم والتصوير، الأثكال

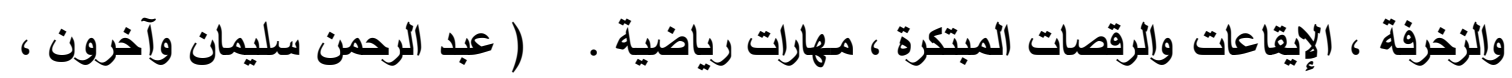
(19. ، . . . . )

V- برنامج : هو جميع الخبرات المخططة التي تعدها المعلمة والتي يمر بها الأطفال داخل الروضة وخارجها والتي تهدف إلى النمو الثامل للطفل من جميع الجوانب الجسمية والعقلية والاجتماعية التهية والوجدانية .

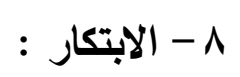

الابتكار نوع من التفكير في أي مجال ينطلق فيه الفرد على غير ما اصطلحت عليه الجماعة ، منتجاً

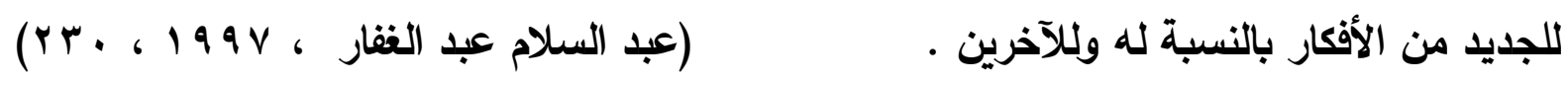


والابتكار في المعجم الفلسفي يعني لغـة إحداث شيء على غير مثال سـابق ، ويعني إيجاد شيء

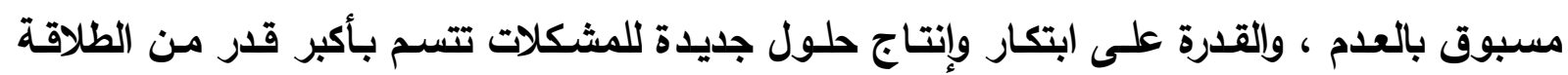

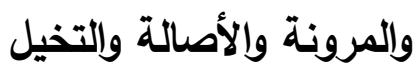

9 - الطفل الموهوب Gifted child لفظ يطلق على أي طفل يزيد استعداده العقلي وأداؤه عن

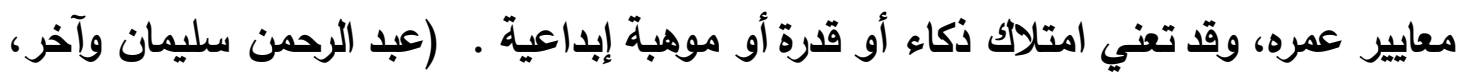
- ( IV ، Y... )

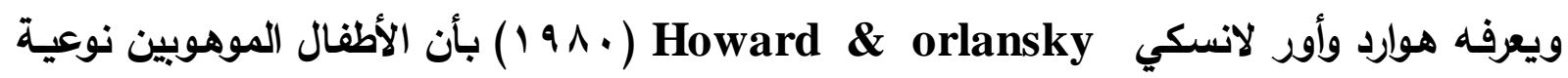

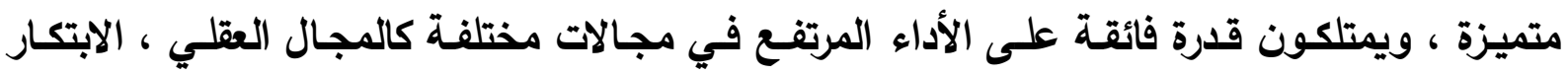
والتحصيل ، والفنون والقيادة الاجتماعية .

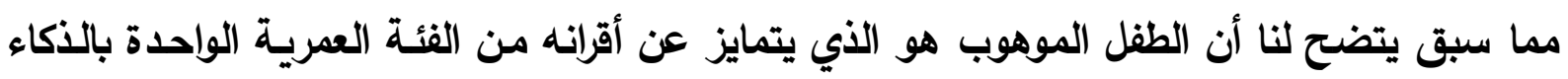
وسرعة الفهم والقدرة على التعلم والتفوق الدراسي الأكاديمي والثني .

أولا : الإطار النظري

حقائب التقييم Portfolio من الاتجاهات المعاصرة الآن وجود مجموعة من الطرق والأدوات الحديثة تجمعت تحت مظلة التقييم

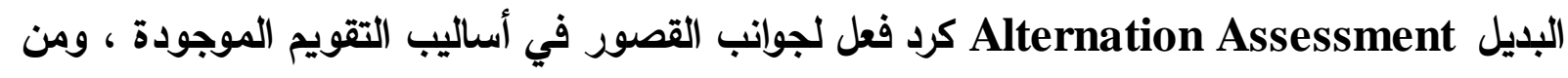
هذه الأساليب " حقائب التعلم ، صحائف المتعلم ، مقاييس التقدير ، تقويم المشاركين ، تقييم الأقران . تقويم البورتفوليات : علي مدي سنوات عديدة ماضية كان المتخصصون بتقويم الطفل مهتمين بالبحث عن أساليب جيدة

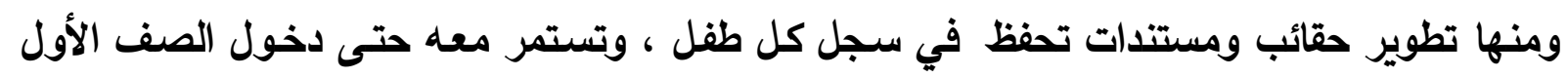

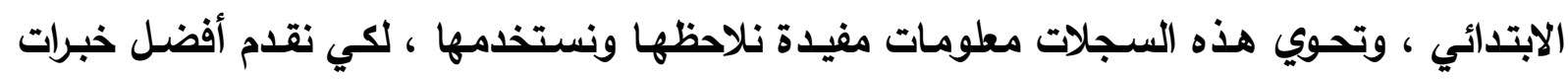

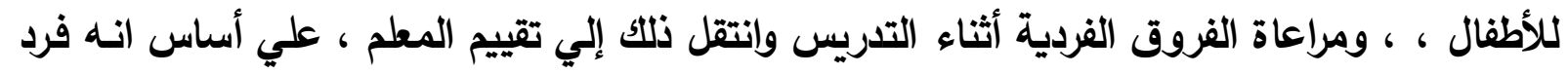

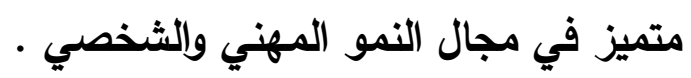

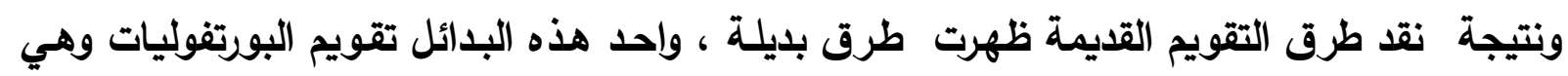

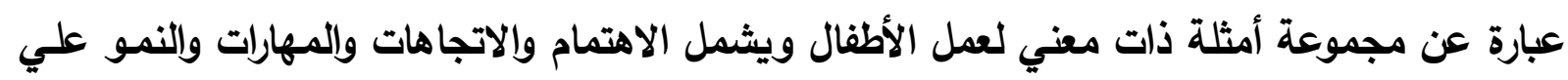
(galefer\&perkings,1996,p.5)

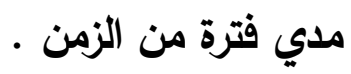

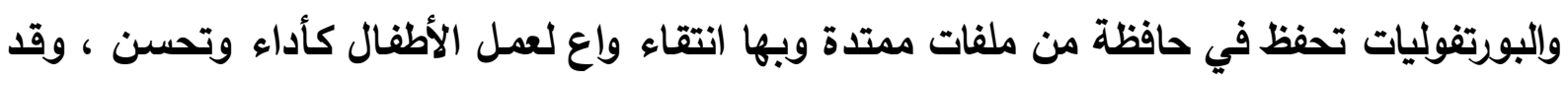

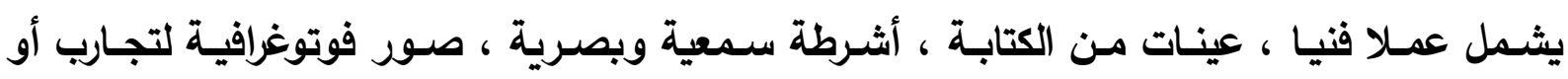


مشروعات ، ملاحظات المعلم أو الوالد ، ملاحظات قصصية ،قوائم مراجعة ،تقويمات ذاتية ، قوائم

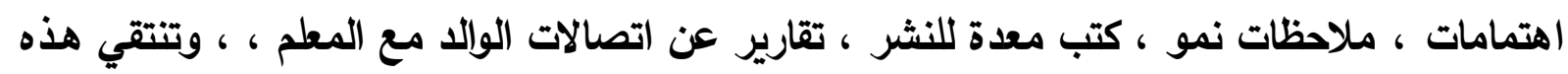

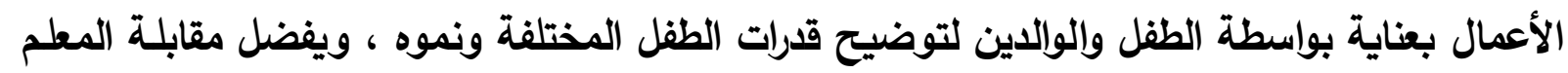

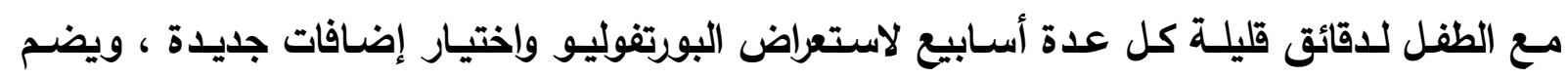

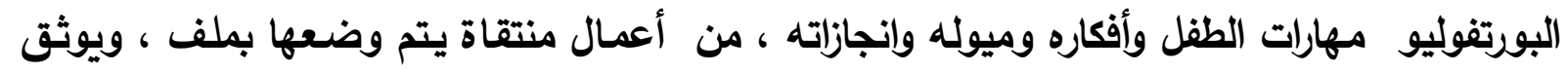

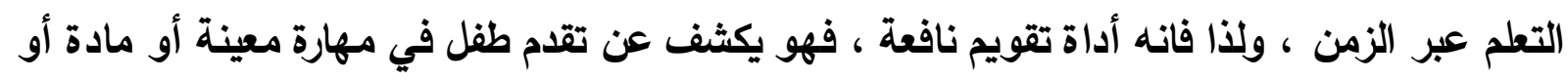

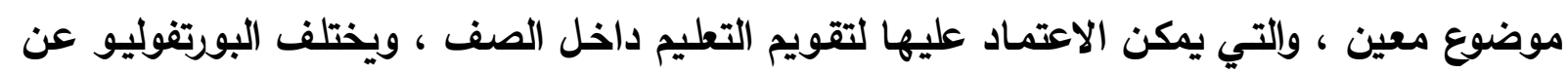

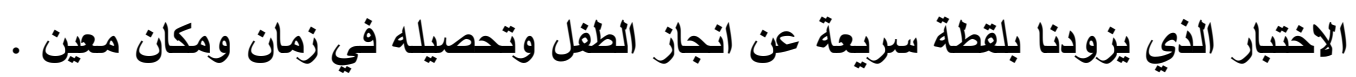

أهداف البورتفوليو إذا أحسن تصميمه يمكن أن يحقق الأهداف الآتية : • يتيح للمعلم تقييم نمو الطفل .

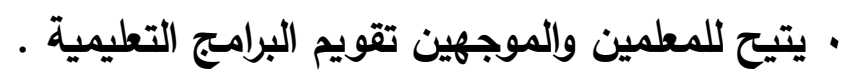
• يتيح للأطفال مشاركة المعلم في التقييم .

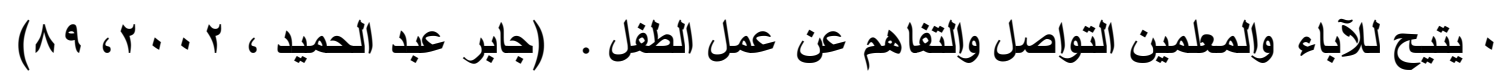

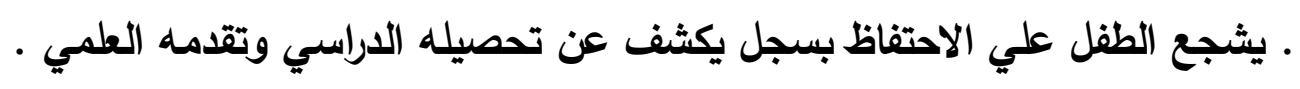

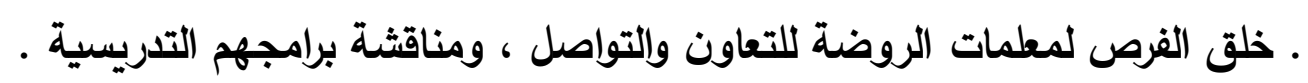

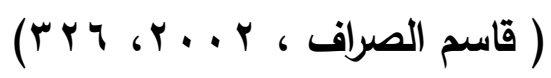

وهذه الأهداف تؤكد علي التقويم الذاتي من خلال مشاركة الطفل في التقييم ، وربط المنزل بالروضة

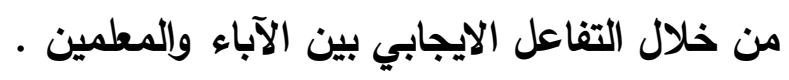

$$
\text { فوائد استخدام البورتفوليو : }
$$

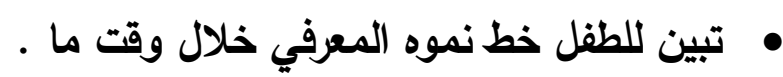

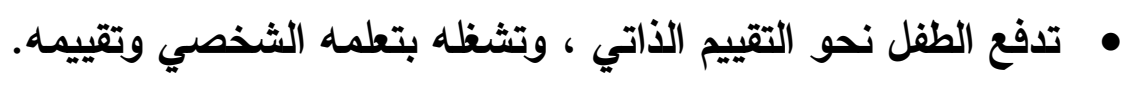

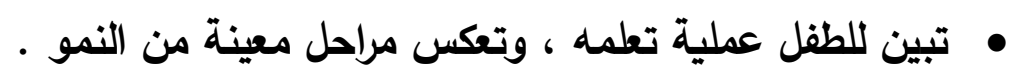

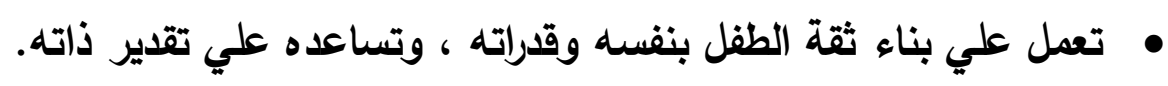

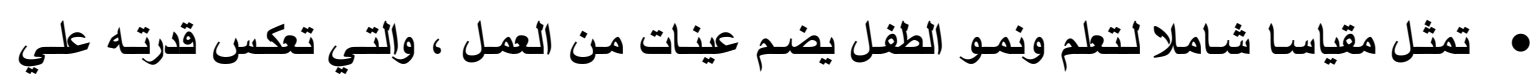

التحصيل . تمثن

• تمثل خبرة تعليمية بذاتها ، فكلما نمت الحقيبة اتضحت أهداف التعليم للطفل ، وتساعد الطفل

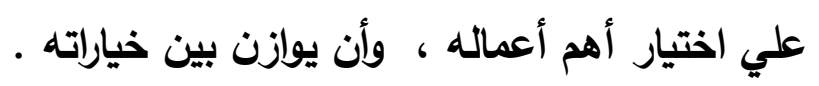

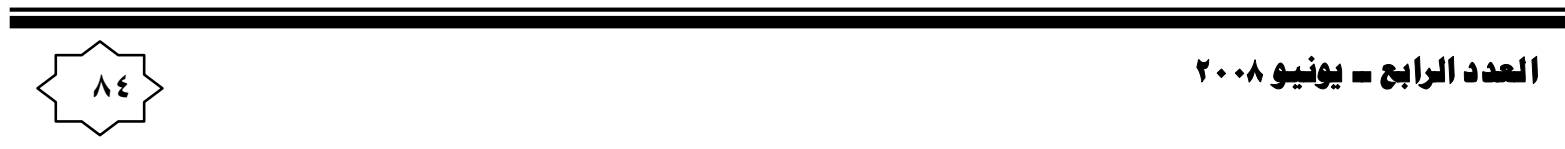


• مفيدة للمتعلم الباحث عن التوظيف ، فالحقيبة تبين السيرة الذاتية للفرد ، فبعض المدارس

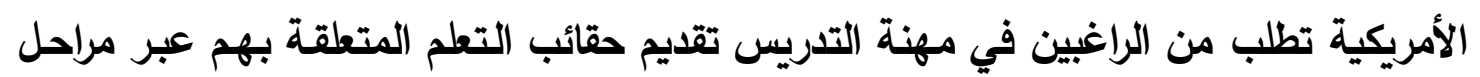

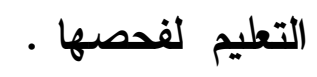
• تبين جوانب القصور والفجوات الموجودة في برامج التعلم •

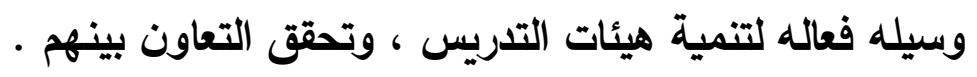

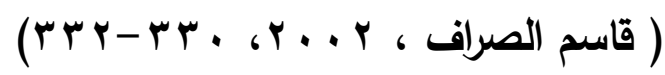

• يوضح معلومات مهمة عن الأطفال في الفصل عن طريق الملاحظة المستمرة لمجالات نموهم .

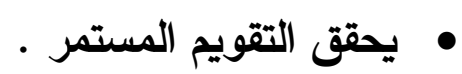

• مشـاركة الجميع في التقـويم ( الآبـاء ، معلمي الصـف ، الأخصـائيين النفسي والاجتمـاعي والمهني ، الطبيب) لاتخاذ قرارات تعليمية وعلاجية وإرشادية أفضل للأطفال .

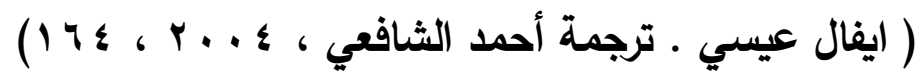

شروط استخدم تقييم البورتفوليو :

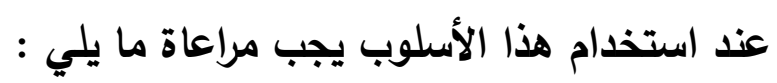
1 - الغرض المحدد الذي سوف يستخدم البورتفوليو من اجله ، وتحديد محتويات الحقيبة.

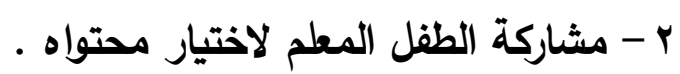

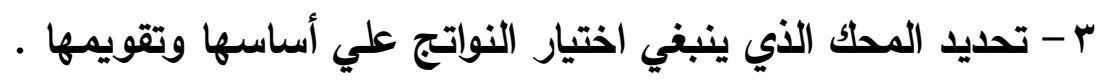

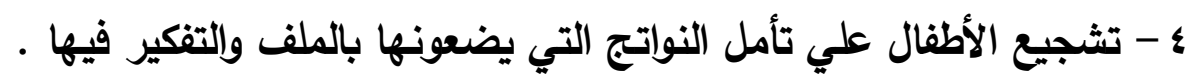
ه - تحديد نواحي القوة والضعف في استخدامه والتقويم النهائي أو التجميعي . צ - تقرير الثيء الذي يجب جمعه ، وبواسطة من ومتى ، و مكان وضئ ولفع الحقائب ، وكيفية تقييم محتوياتها . متريز العي

ولكي يكون استخدامه علي نحو فعال يمكن إضافة ما يلي :

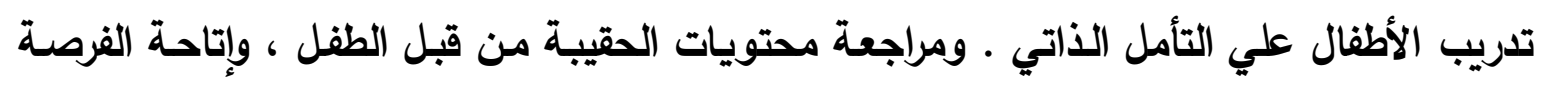

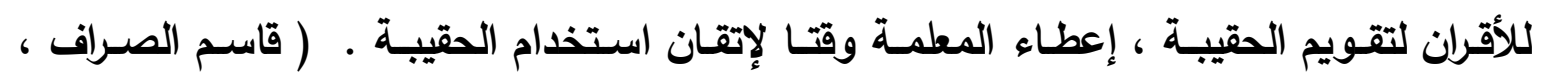
(rr r r r...r 
محتوي البورتفوليو :

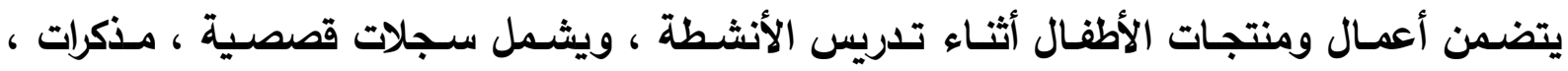

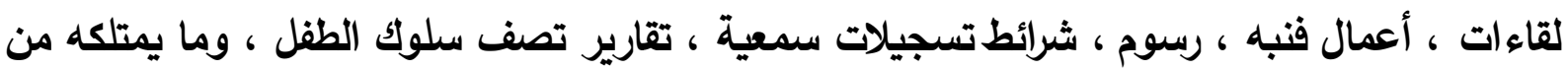
مواهب وقدرات ، والتعرف علي ميوله واتجاهاته وحاجاته . ويجب أن تحتوي حقيبة التقييم المواد التالية :

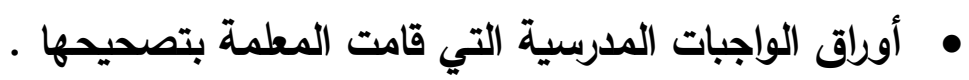

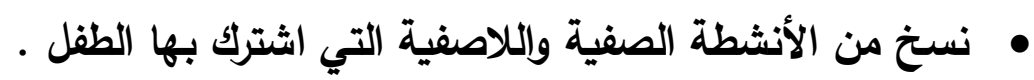
• مذكرات الطفل ورسوماته الفنية وكتبه المصورة والمرتبطة بالأنثطة .

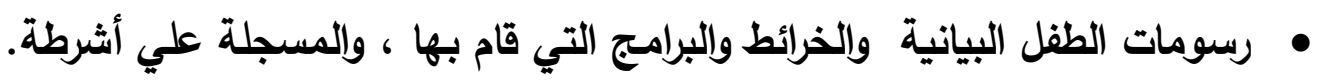

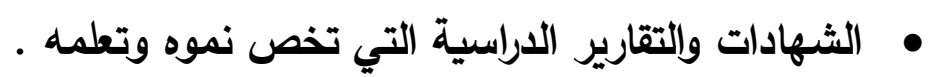

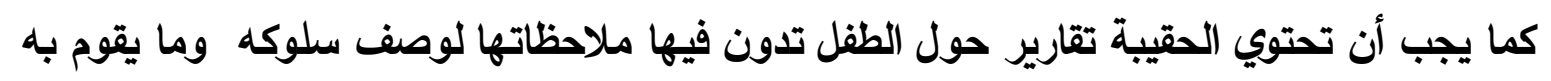

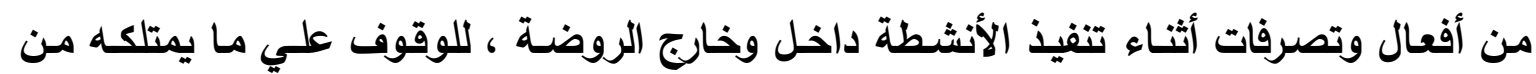

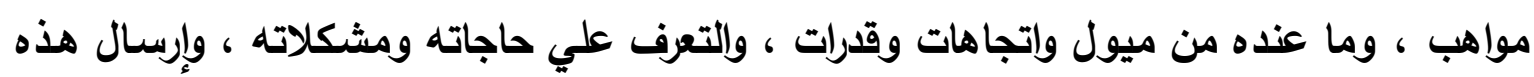

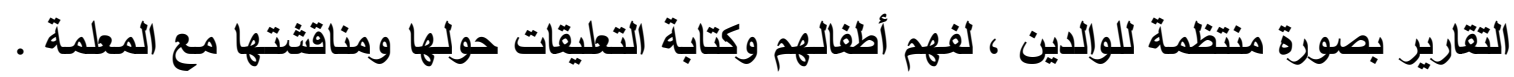

$$
\text { أنواع التقارير }
$$

"التقرير اليومي :يتضمن وصفا شامل لنشـاط الطفل " أقوالـه وأفعالده"، خلال فترة زمنية من اليوم

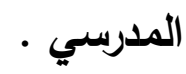
*التقرير القصصي : لكشف نمو الطفل في جانب معين خـلال فترة معينة ، حيث تسجل المعلمـة ملحوظات عن حادثة معينة خلال فصل دراسي كامل .

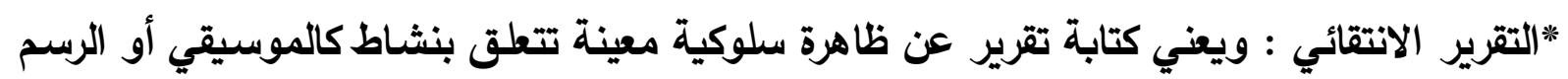

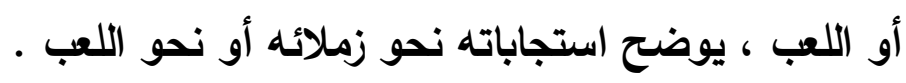

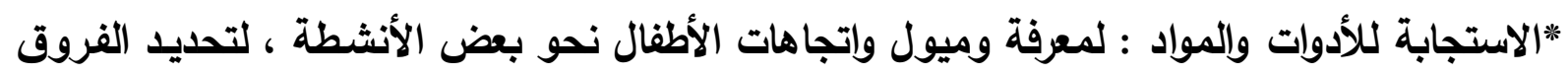
الفردية وتصنيف الأطفال في مجموعات . "تقرير عن لعب الطفل بمفرده أو داخل مجموعة : للوقوف علي ايجابية الطفل وتفاعله مـع زملائهـ

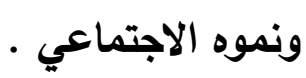
"البطاقة الصحية والأحسوال الثخصية : يثترك الوالدين والمعلمـة بتعبئة البطاقة بمسـاعدة الطبيب للوقوف علي الحالة الصحية والجسمية من ولادته حتى التحاقه بالروضة ، لتفسير سلوكه واتخاذ القرار المناسب . 


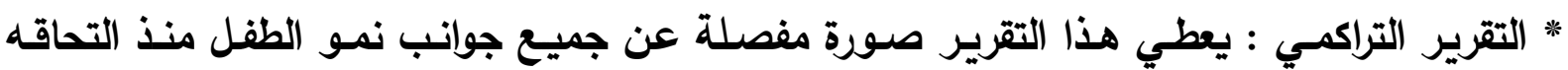

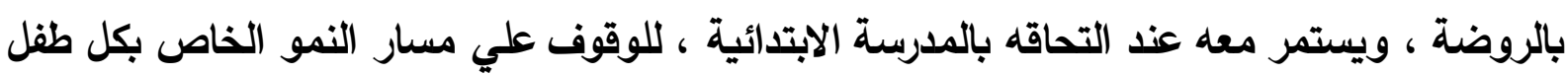

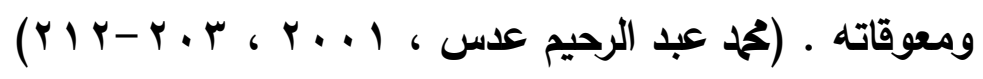

اختيار عينة العمل

لقد طور الباحثون في مجال التقويم أدوات بليلة للتظلب علي صعوبات التقويم التقليدي وإلحصول علي أدوات ثابتة وصادقة ، فلقد اقترح مزلز (Meisels 1993) نظام عينات العمل أي تجميع بيانات عن الطفل خلال فترة طويلة ، وتسجل هذه الملاحظات وتصنف حسب مجاته مجالات النمو وتثمل

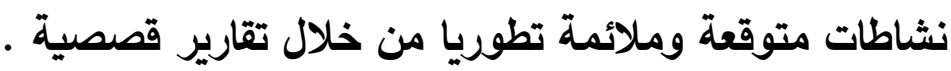

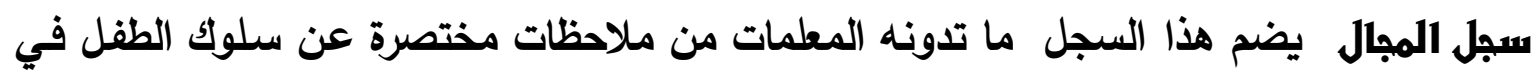

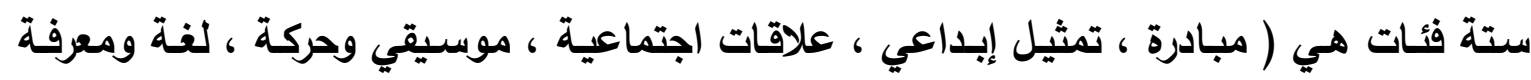

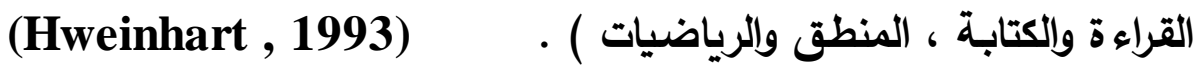

تعريف الابتكار : الابتكار الابتكار في المعجم الفلسفي يعني لغة إحداث شيء على غير مثال سابق ،وقد اتفق الحكماء على أن

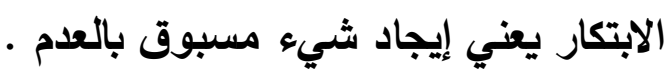

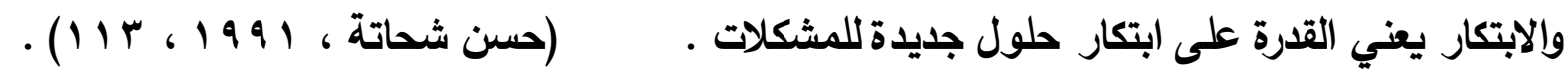

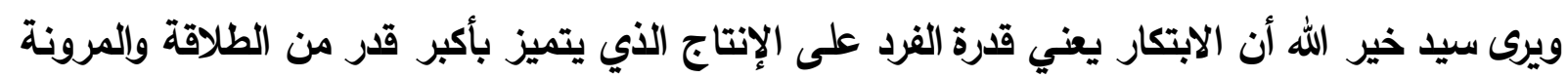

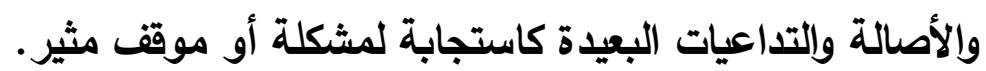

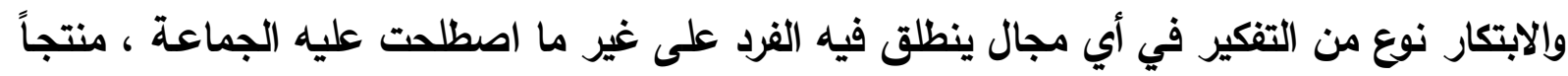

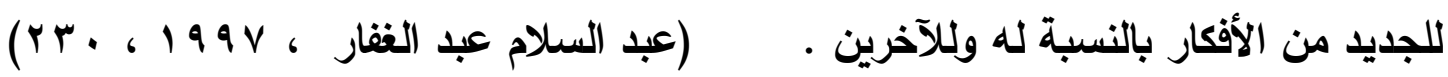

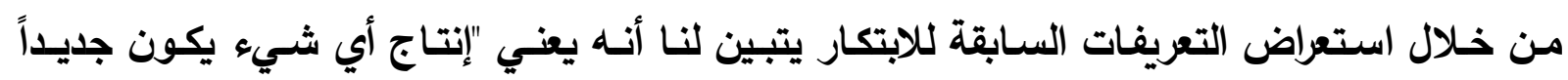

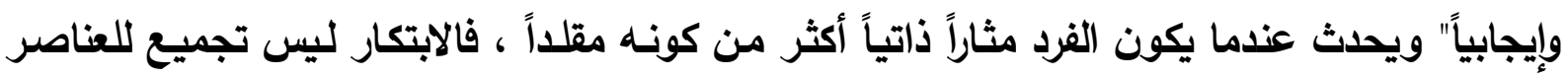

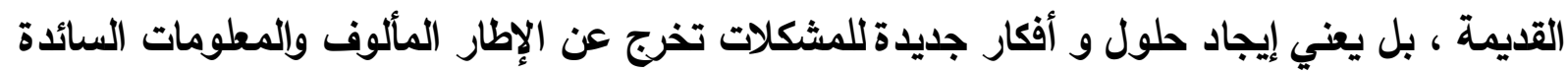

في البيئة" ويتألف التفكير ألابتكاري من مجموعة من القدرات والتي من بينها ما يلي: الطلاقة Fluency : وهي القدرة على إنتاج أكبر عدد من الأفكار أو الاستجابات (رموز -

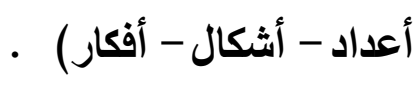


(r)(الأصـالة Originality مألوفة . (r)(المرونة Flexibility

وهناك بعض الطرق والأساليب لتنمية الابتكار برياض الأطفال ومن بينها:

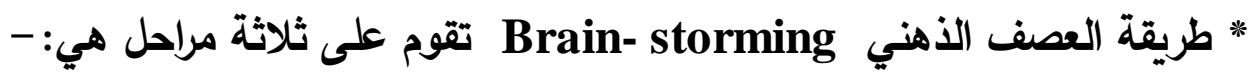

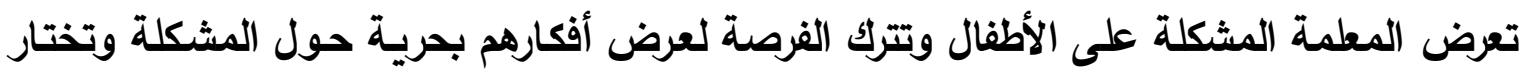

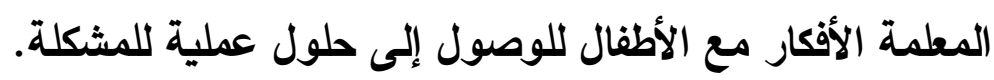

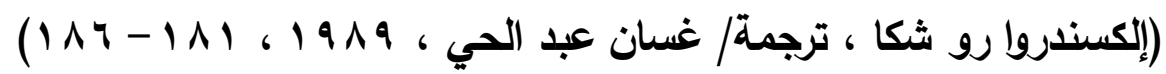

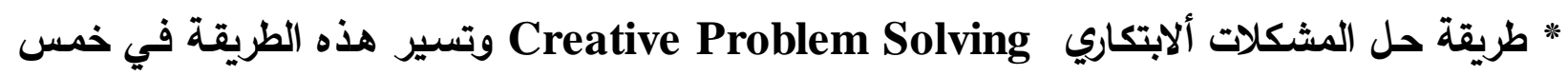
خطوات وهي جمع الحقائق المتعلقة بالمشكلة،طرح الحلول المتعددة،اختبار البدائل وإيجاد معيار للحكم على صحة تلك البدائل وقبول الحل المناسب.(Sisk, D. , 1987, 108: 110)

* طريقة التقصي والاكتشاف Discovering and Inquiry : وتعد هذه الطريقة ذو فاعلية كبيرة مع : Sisk, D. , 1987, 102: الأطفال خاصة المبتكرين وتساعدهم على التنبؤ والتفكير الإنتاجي والتجريب.

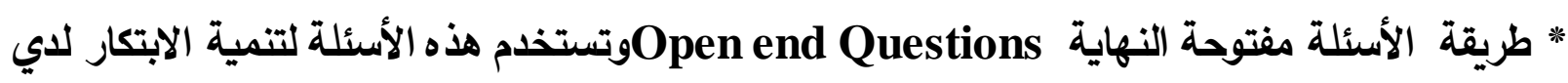

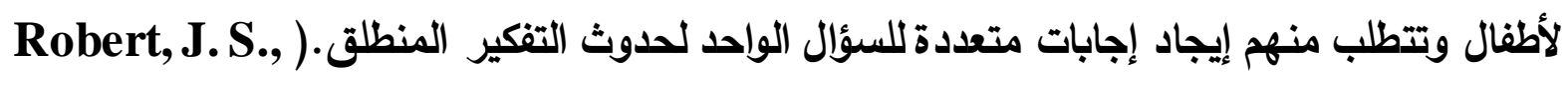
.(1999, P274

* الألعاب التعليمية : Scientific Games وهذه تعطي فرص كثيرة للأطفال للابتكار وسرعة البديهة

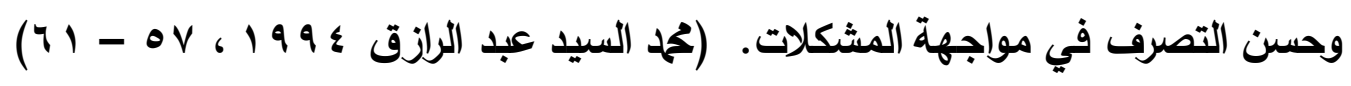

الدراسات السابقة أولا : دراسات تدور حول أهمية استخدام تقويم البورتفوليو برياض الأطفال : 
ا - دراسة مزلس meisels(1995) الذي فص هو وزملاؤه الثبات والصدق لطرق تقويم بديلة ،

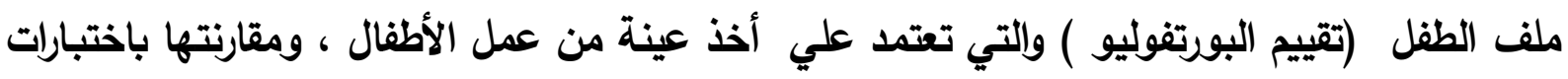

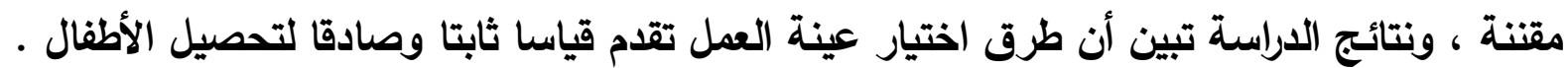

r - دراسة بودين ، شيلي هلسن Bowden, Shelly Hudson (2005) التي توصلت إلي أن استخدام الحقيبة التعليمية والتي بها صور تكون مناسبة للتعلم برياض الأطفال خلال اليوم الكامل ، كما أنها تسـاعد المعلمة علي إجراء التجارب بقاعة النشاط لتدعيم معرفة القراءة وإلكتابة الطبيعية لكأطفال .

r - دراسة نيكو ، أنيل Niikko, Anneli (2002) التي تحققت من فاعلية بعض الأساليب والطرق

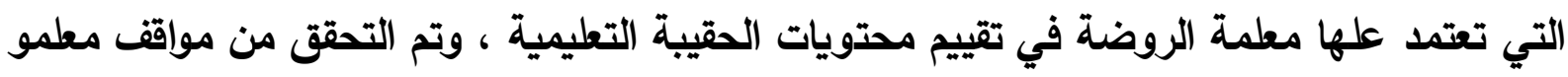

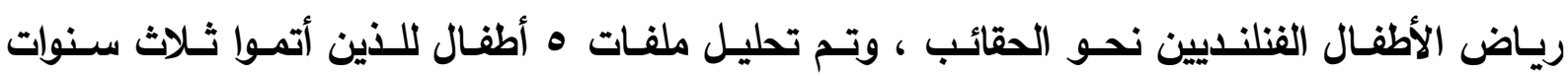

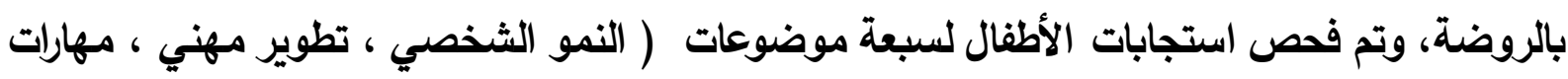

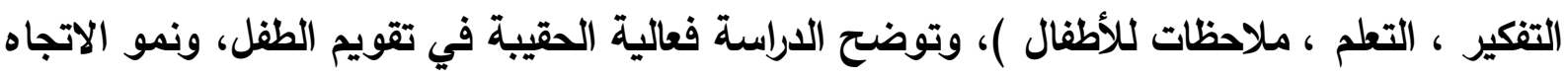

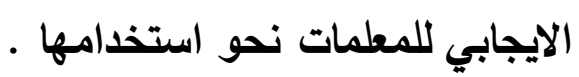

؛ - - دراسة كانكانرانتا ، مارجا Kankaanranta, Marja (2001) التي اهتمت بتصميم حقائب رقمية لتطوير قدرات المعلمين علي استخدام تكنولوجيا المطومات والاتصالات في التعليم ، فلقد تحقق دانق

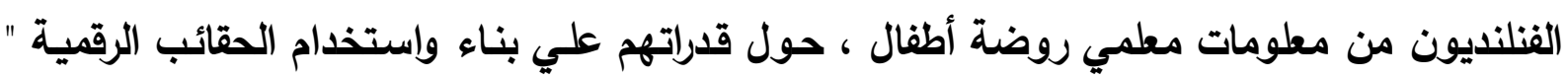

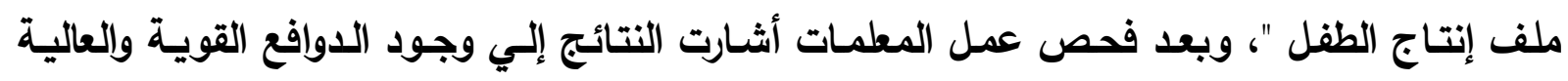

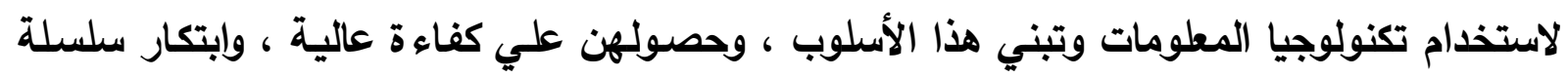
كاملة متعددة الأشكال لتطوير الحقيبة.

هall, Bruce W.; Hewitt-Gervais, هول بـروس دبليـو ، هيوايت وآخرون Cynthia(2000)

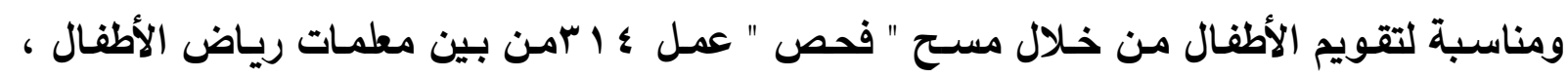

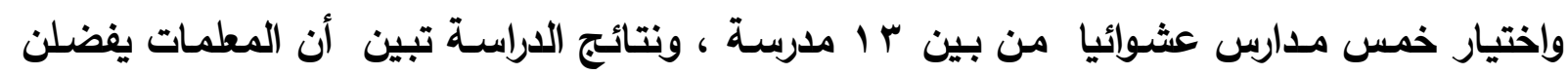

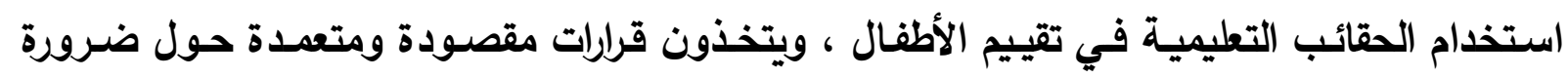


استخدام الحقائب وتطبيقها بقاعة الدروس ، وساهم هذا في رفع مستوي أطفالهم ونموهم ، واستخدام أسلوب الملاحظة الهادفة أثناء تنفيذ الأنشطة .

4 - دراسة بالم سالي ،ماري (1995) Balm, Sally St. Mary ، التي تدور حول استخدام تقييم

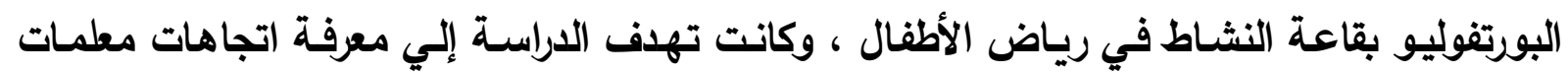

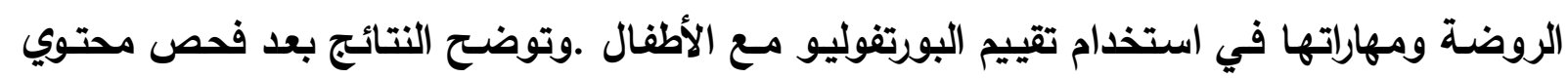

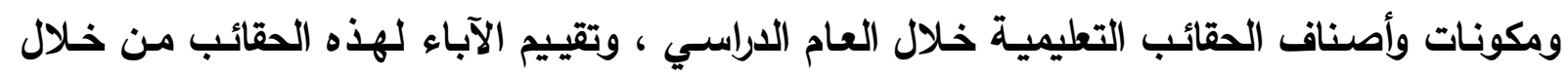

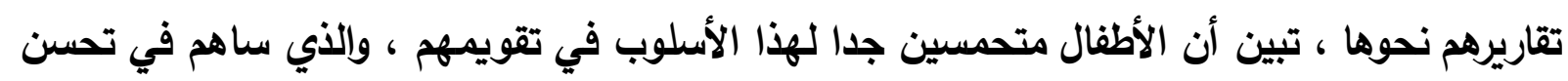
جميع جوانب نموهم .

v - دراسة ورنر،لافرن ، أدمزبولي Warner, Laverne; Adams, Polly (1996) ، التي تركز علي قيام المطمين بإجراء دراسات حول أطفالهم عن الطرق المناسبة لتحسين إدارة جوانب العمل

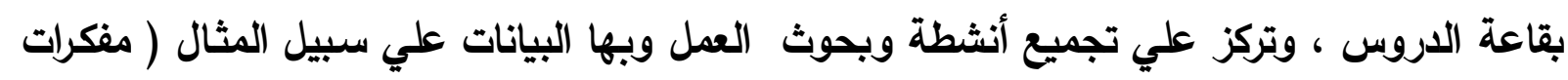

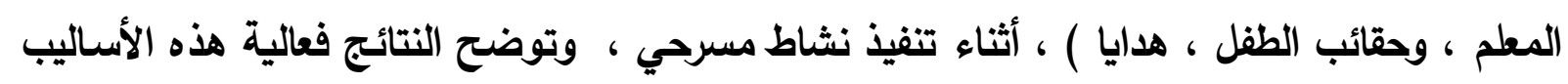

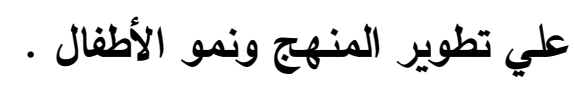

1 - دراسة هودجر وآخر (1994) Hodges, V. Pauline ، التي توصلت إلي بعض الاستراتيجيات

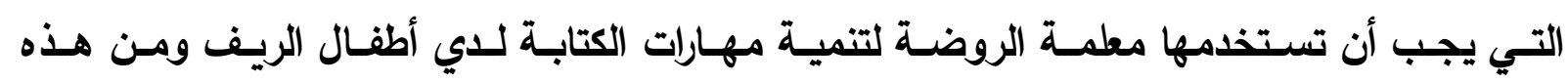

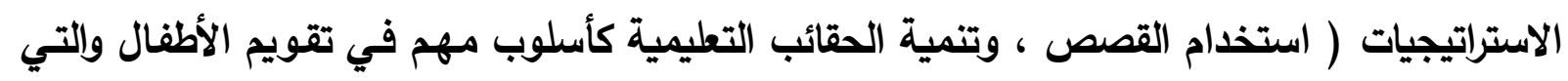
تتضمن وصف عمل الطفل ) وساهم ذلك في دفع الطفل للمشاركة في موقف التعلم والتأليف ومنهج

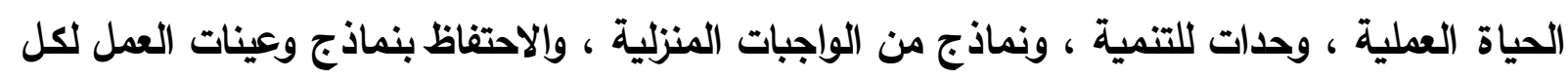

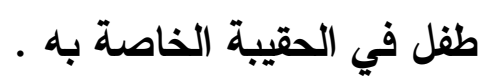

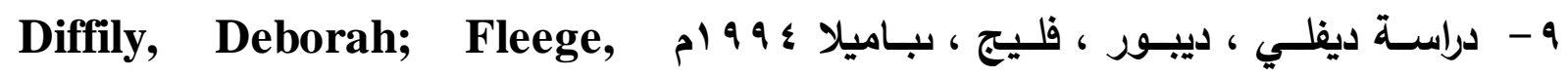

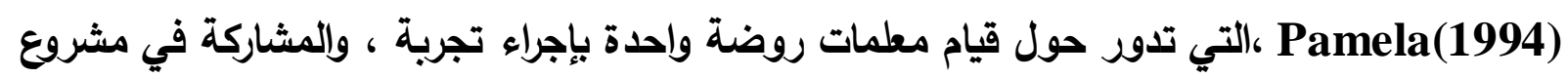

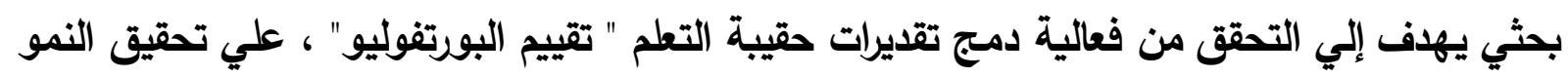

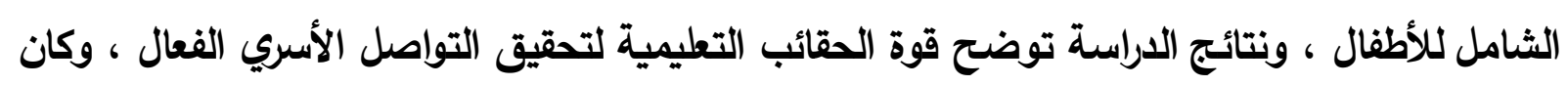
لها تأثيرا كبيرا علي نمو الأطفال ، وتقدم الآباء . 
• 1 - دراسـة ميسلز صمؤيل وآخرون Meisels, Samuel J.; And Others(1995) ، والتي

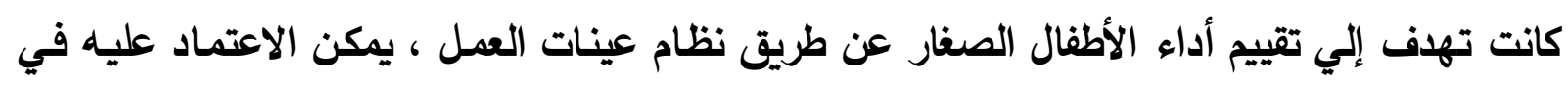

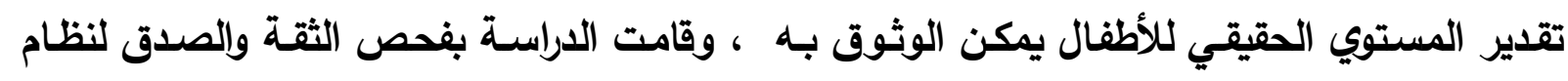

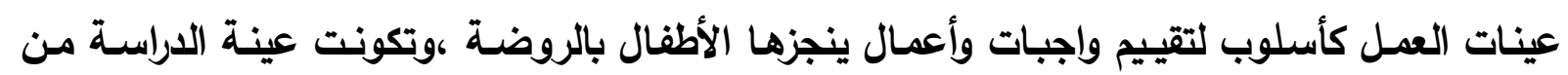

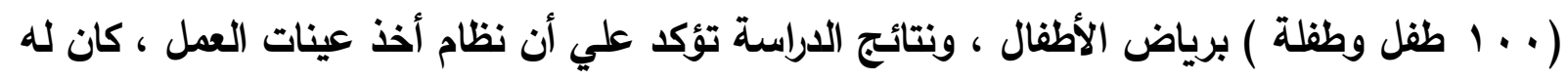

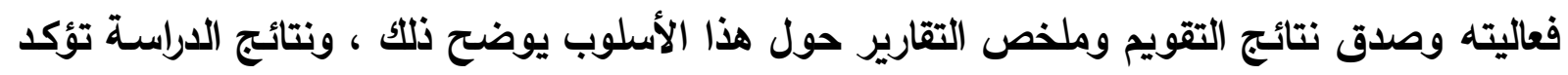

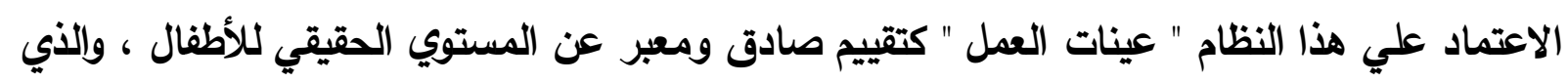

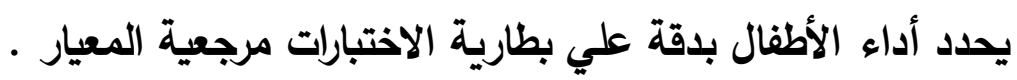
ويري الباحث أن أسلوب التقويم الذي يعتمد علي أخذ عينات العمل من أهم الركائز التي يستند إليها لإيها

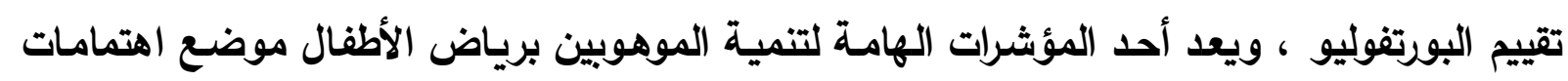

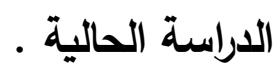

ثانيا : الدراسات التي تدور حول تنمية الابتكار لاي أطفال الروضة

توجد العديد من الدراسـات التي تناولت أسـاليب تنمية التفكير ألابتكاري لأطفال الروضـة من خـلال

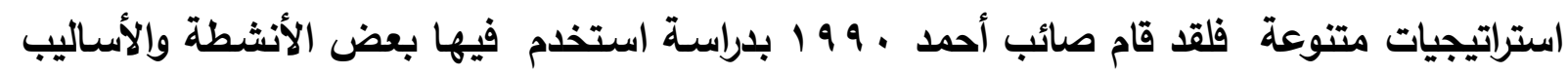

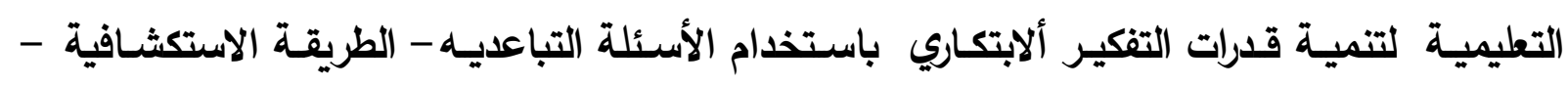
العصف الذهني - الألغاز المصورة، الألعاب التعليمية ،ولقد أوضحت دراسة فولر (Fowler،1997)

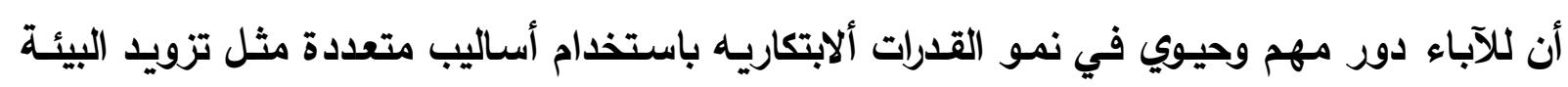

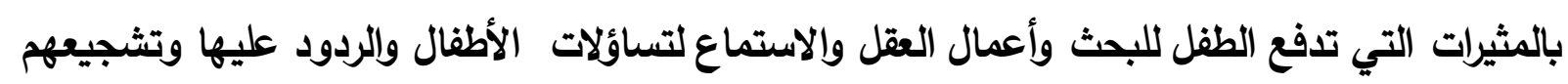

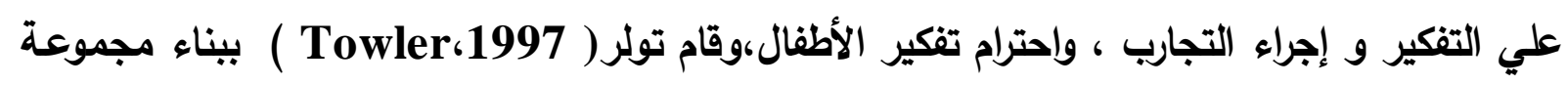

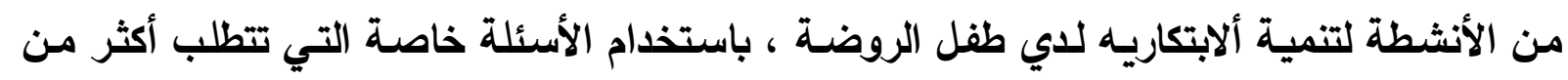

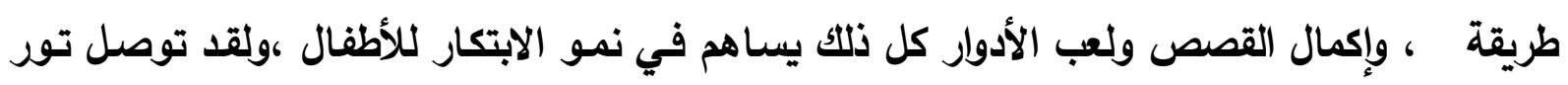
انس وجوف (Torrance and gaffe 1990) إلى أن للمعلمات دور بارز في تنمية التفكير ألابتكاري للأطفال عن طريق الاهتمام بالأسئلة غير العادية ،والتشجيع عليها واحترام الأفكار والحلول

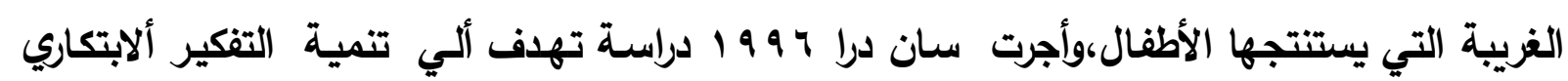

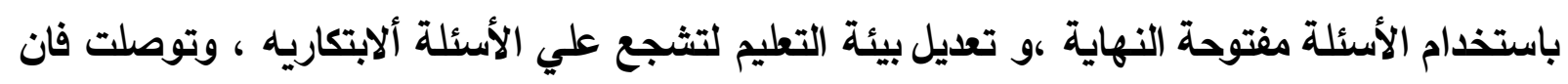

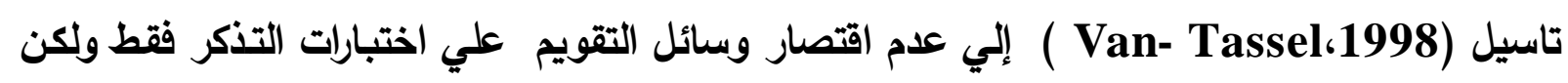

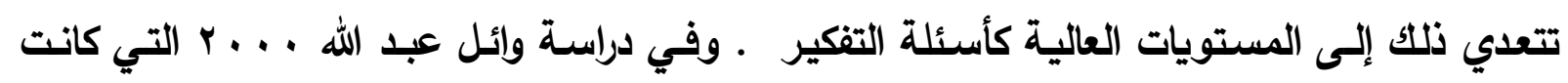


تهدف إلي بناء برنامج إثرائي في الرياضيات لتنمية قدرات التفكير ألابتكاري برياض الأطفال باستخدام

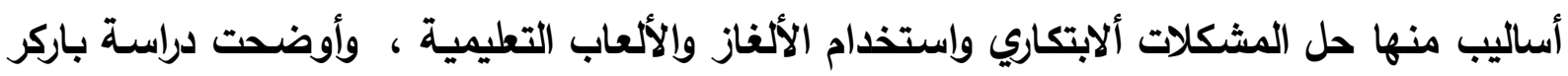

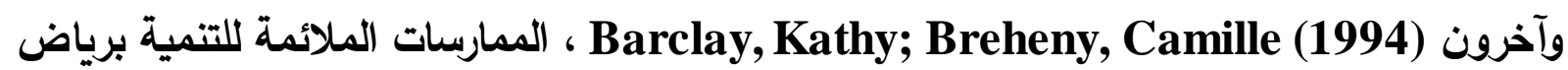

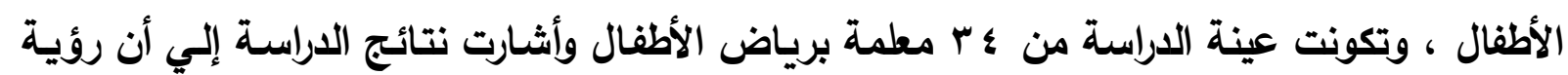

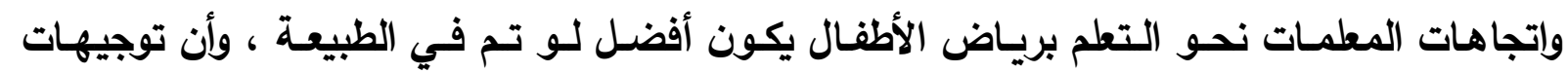

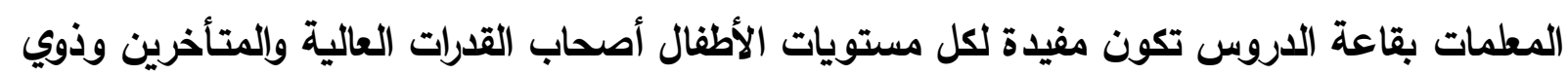

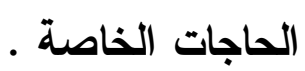

تعليق عام علي الدراسات السابقة من خلال عرض الاراسات السابقة نستنتج ما يلي : 1 - معظم الدراسات اتفقت علي أهمية الاعتماد علي أسلوب تقييم البورتفوليو كأداة فعالة ومناسبة

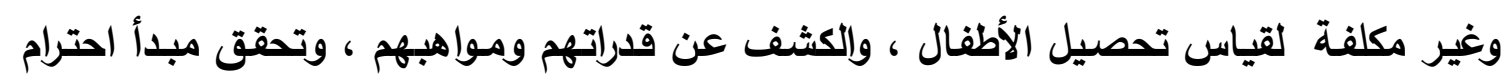

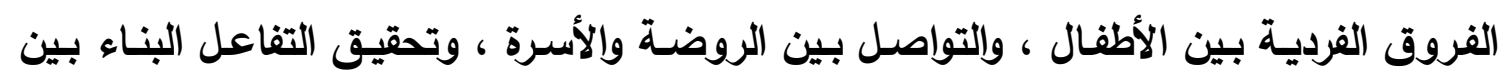

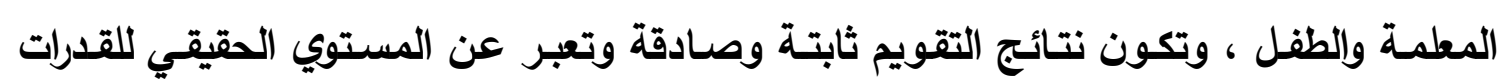

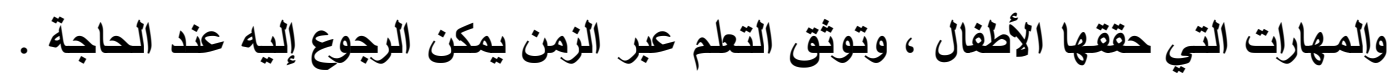

ץ - يمكن تنمية الابتكار لاي أطفال الروضة من خلال استخدام بع الأساليب والطرق مثل ( طريقة

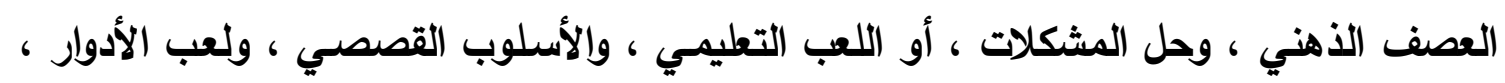

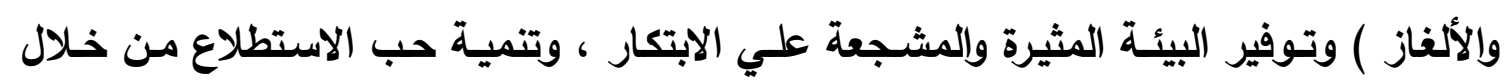

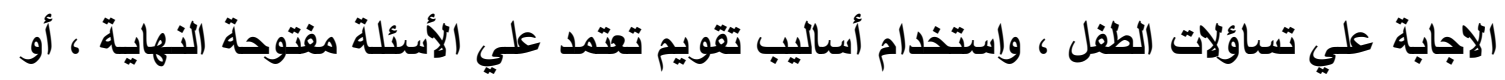

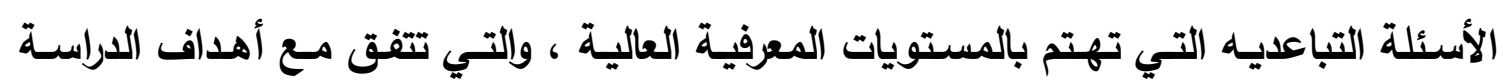

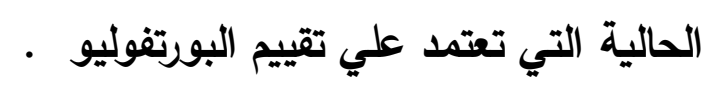

\section{فروض الدراستة}

من خلال الإطار النظري والدراسات السابقة يستطيع الباحث توقع الفروض الآتية:

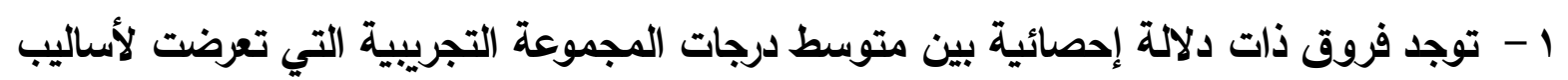

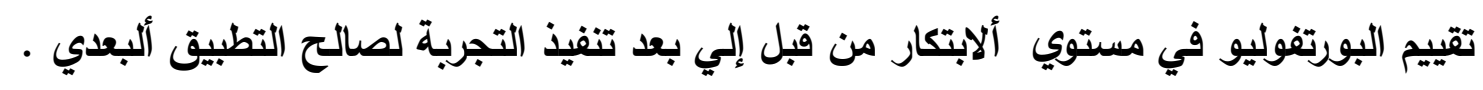

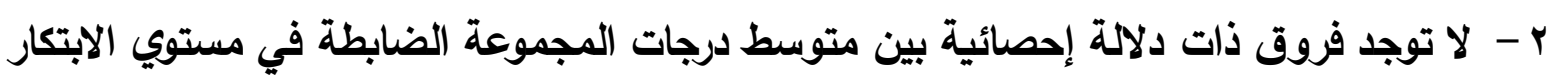

بين التطبيقين القبلي والبعدى دوات دلاده 
r- توجد فروق ذات دلالة إحصائية بين متوسط درجات أطفال المجموعتين التجريبية والضابطة

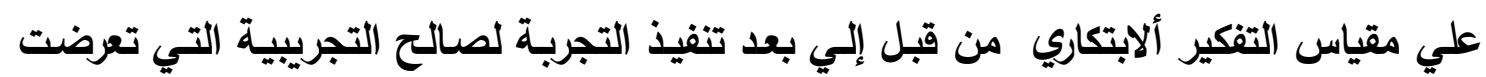

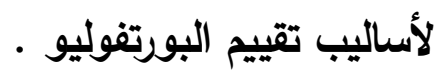

إجراءات الدراسة منهج البحث : تم استخدام المنهج التجريبي الذي يتمشي مع طبيعة الدراسة.

$$
\text { أ - عينة الدراسة : }
$$

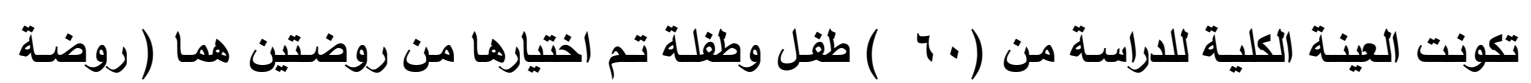

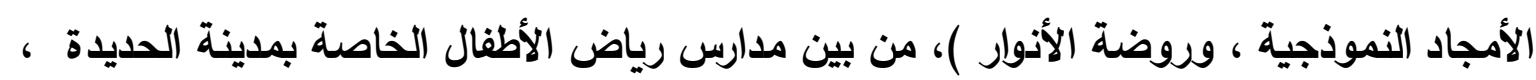

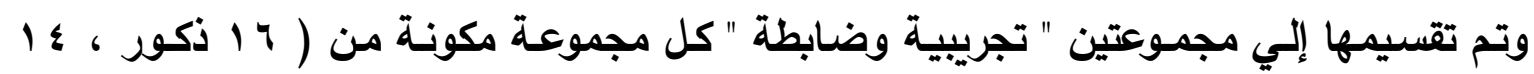

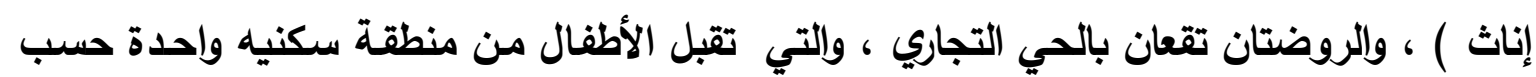

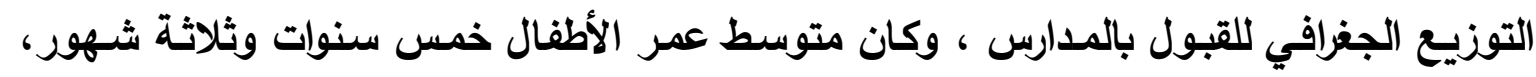

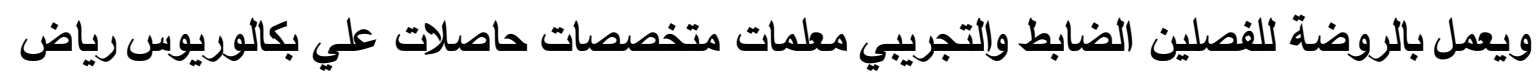

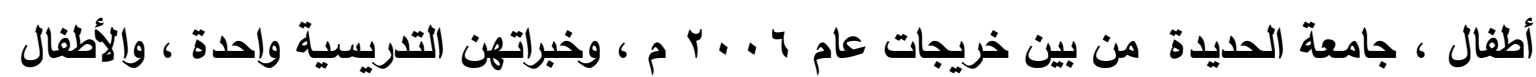

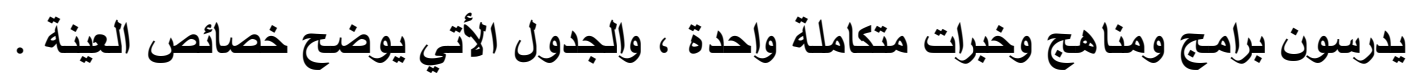

$$
\text { جدول رقم (1) }
$$

\begin{tabular}{|c|c|c|c|c|c|c|c|}
\hline \multirow{2}{*}{ 歺 } & \multicolumn{2}{|c|}{ عدد الأطفال } & \multirow{2}{*}{ المجموعة } & \multirow[b]{2}{*}{ عدد المعلمات } & \multirow{2}{*}{ المستوي } & \multirow{2}{*}{ الروضة } & \multirow[b]{2}{*}{ e } \\
\hline & 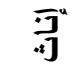 & 羿 & & & & & \\
\hline r. & $1 \varepsilon$ & 17 & تجريبية & معلمتان & K g 2 & الأنوار & 1 \\
\hline$r$. & $1 \varepsilon$ & 17 & ضابطة & معلمتان & Kg 2 & الأمجاد & 2 \\
\hline
\end{tabular}

ب-أدوات الدراسة : استخدم في الدراسة الأدوات الآتية :

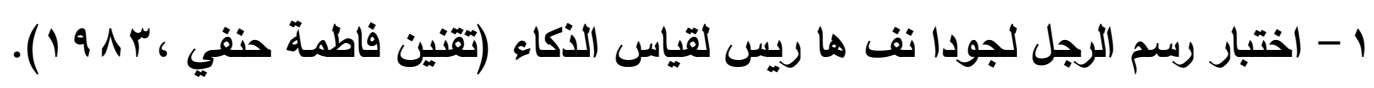




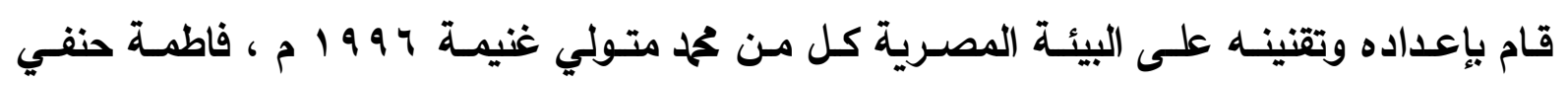

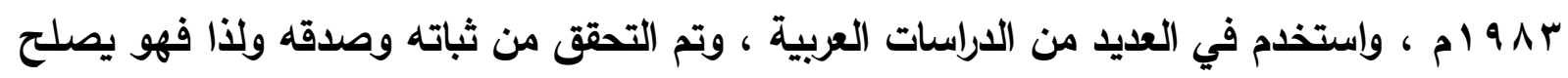

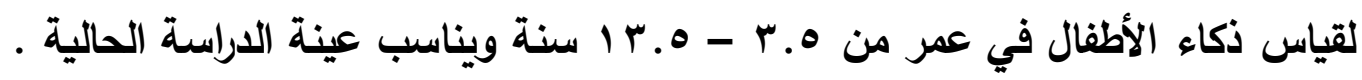
ץ - مقياس المستوى الاجتماعي الاقتصادي للأسرة (إعداد عبد العزيز الثخص ، 999 1).

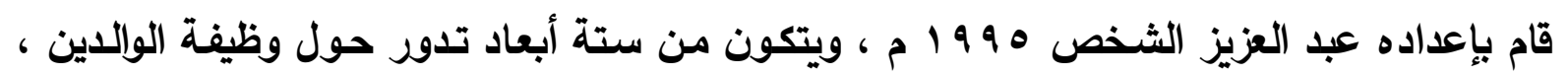

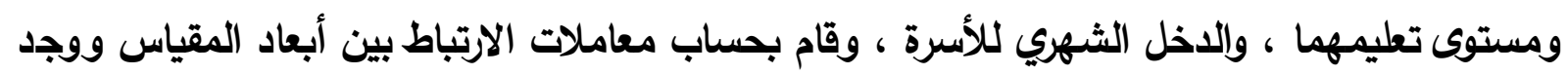

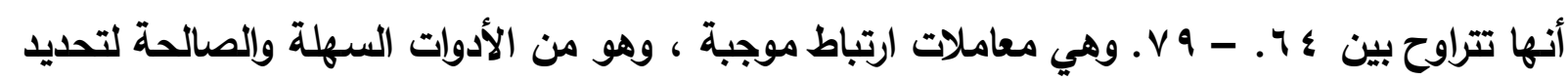

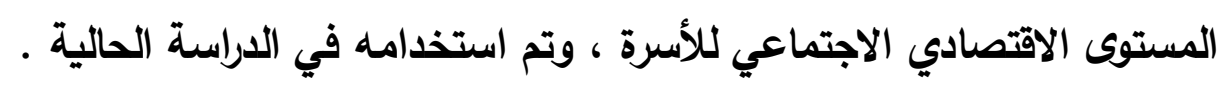

r - اختبار التفكير ألابتكاري باستخدام الحركات والأفعال(إعداد وتقنين محمد ثابت ، ج ج ام).

قام تورا نس بتصميمه ليناسب الأطفال من r V- سنوات ، وقام محمد ثابت بترجمة المقياس وتقنيته

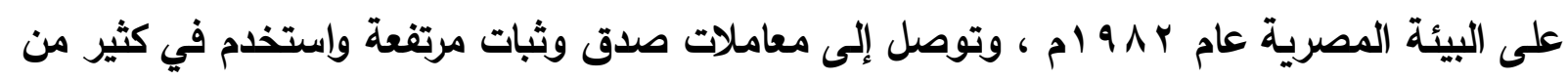

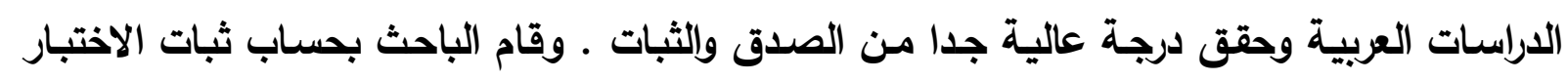

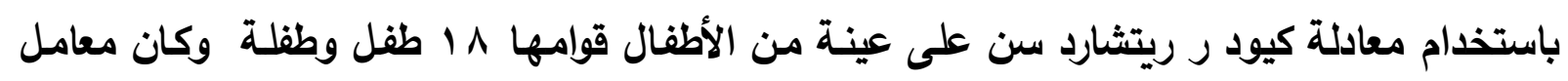

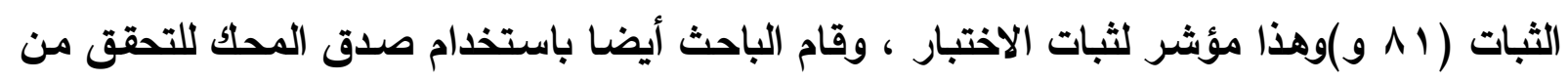

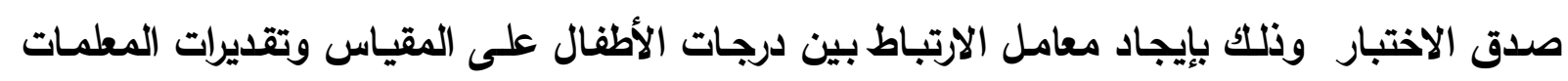

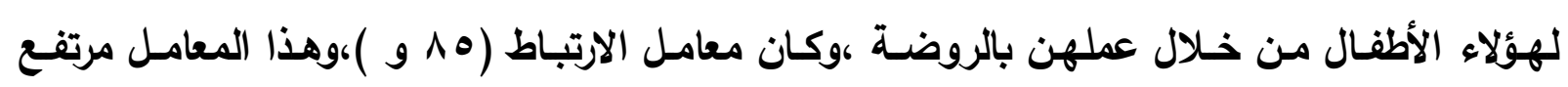
ومرضى ويمكن الوثوق به علميا .

وصف الاختبار :- يتكون الاختبار من أربعة أنشطة كما يلي : النشاط الأول : كم طريقة ؟ ويقيس قدرة الطفل على الطلاقة والأصالة. النشاط الثاني : هل تقدر تتحرك مثل ؟ ويقيس قدرة الأطفال على التخيل وتقليد الأدوار غير المألوفة . النشاط الثالث : ما الطرق الأخرى ؟ ويقيس قدرة الأطفال على الطلاقة والأصالة النشاط الرابع : ماذا يمكن أن تكون ؟ ويقيس قدرة الطفل على الطلاقة والأصالة . ع - أساليب تقييم البورتفوليو " حقيبة الطفل " (إعداد الباحث ) . 
في ضـوء الإطـار النظري للبحث واللاراسـات السـابقة ، استطاع الباحث اختيـار أسـاليب تقيـيم

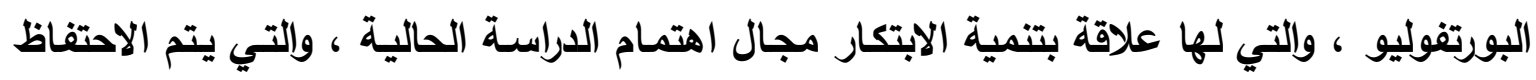

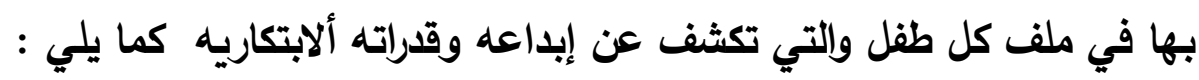

1 - هود الطفل وإنتاجه أثناء تنفيذ الأنشطة والبرامج اليومية والتي تكثف عن تقدمه وتفوقه الاراسي في تحصيل الأنشطة والخبرات المتكاملة .

r - بطاقات ملاحظة لجوانب نمـو الطفل عبر فترة زمنيـة ، أثناء الأنشطة الحـرة بالأركان

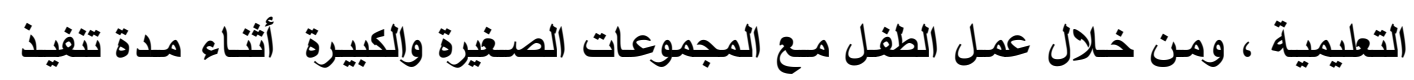
التجربة

r - اختيار عينات العمل أثناء تدريس الأنثطة المتكاملة اليومية وتصنيفها في ستة مجالات

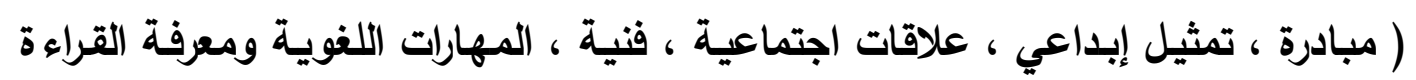

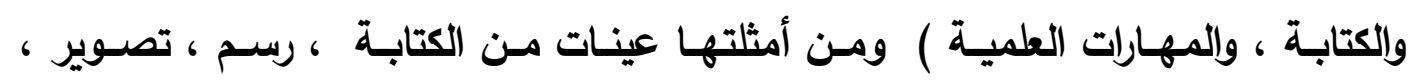

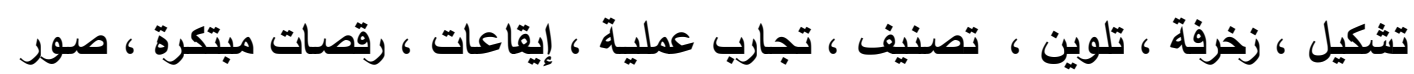

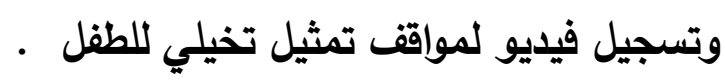

ـ - تقوم المعلمة باتخاذ قرارات حول انجازات كل طفل ، وتحديد قراته ومهاراته الإبداعية

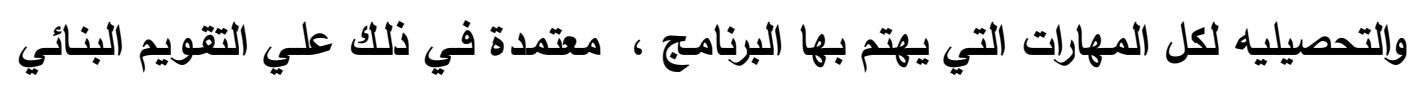

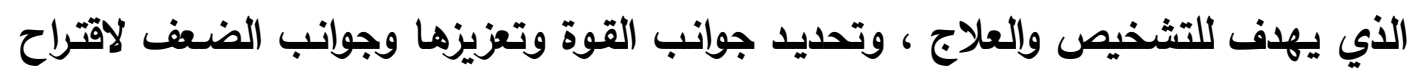

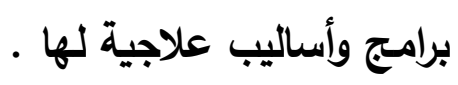

- - - تعد المعلمة للطفل المتفوق والموهوب برنامج إثرائي يتحدي قدراته العقلية ويدفعه للبحث

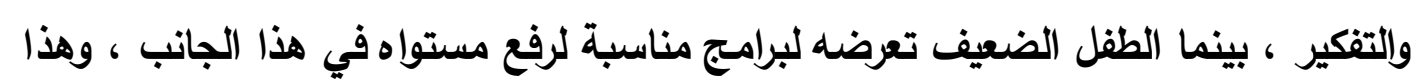

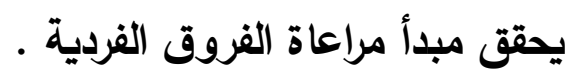




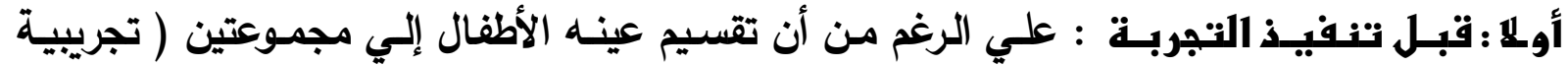

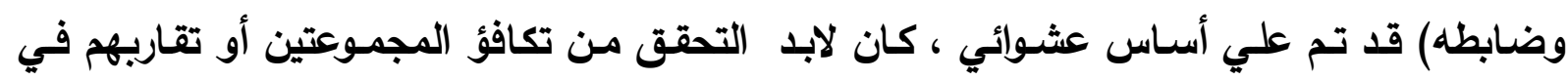

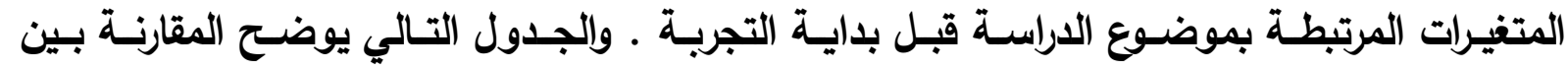

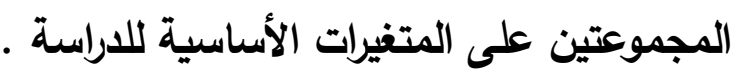

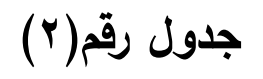

للمقارنة بين المجموعتين ( التجريبية والضابطة) قبل باية التجربة.

\begin{tabular}{|c|c|c|}
\hline الضابطة المجموعـــة & التجريبية & وجه المقارنة \\
\hline$r$. & $r$. & عدد الأطفال \\
\hline 14 & 14 & عدد الذكور \\
\hline
\end{tabular}




\begin{tabular}{|c|c|c|}
\hline $1 \leq$ & $1 \leq$ & عد الإناث \\
\hline צ. & 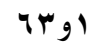 & متوسط العمر الزمني بالثهور \\
\hline 1.1 & 1.0 & الانحراف المعياري للأعمار الزمنية \\
\hline $9 \bullet . \mathrm{r}$ & $94 . \Lambda$ & متوسطة نسبة الأكاء \\
\hline Agr & $9 g \Lambda$ & الانحراف المعياري لنسبة الذكاء \\
\hline \multicolumn{2}{|c|}{ بآو. غير دالة } & قيمة(ت) لالالة الفروق بين متوسطات الاككاء للمجموعتين (تجريبية وضابطة ) \\
\hline $1 \leqslant V g r$ & $1 \leqslant 0, V$ & متوسط المستوي الاجتماعي الاقتصادي للأسرة \\
\hline $1 \leq 99$ & 179 & الانحراف المعياري للمستوي الاجتماعي الاقتصادي للأسرة \\
\hline \multicolumn{2}{|c|}{ ^ب و. غير دالة } & قيمة (ت) لالالة الفروق بين متوسطات المستوي ا(ج ، ص ) للمجموعتين (ت،ض) \\
\hline 1 rg & $\mid r g$ & متوسط التفكير ألابتكاري \\
\hline rgr & rg & الانحراف المعياري للتفكير ألابتكاري \\
\hline \multicolumn{2}{|c|}{ ب آو. غير دالة } & قيمة ت لدلالة الفروق بين متوسطات التفكير ألابتكاري للمجموعتين (ت،ض) \\
\hline
\end{tabular}

ويوضح الجدول السابق مدي التقارب الكبير بين أطفال المجموعتين التجريبية والضابطة علي متغيرات

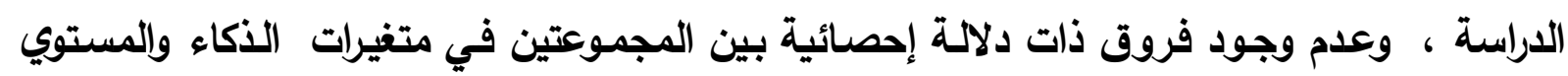

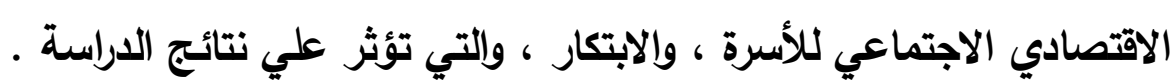
ثانيا : أثناء تنفيذ التجربة "فطة عمل تقبيم البورتثوليو" :

ا - قام الباحث بتدريب معلمات المجموعة التجريبية علي كيفية إعداد حقيبة " ملف " لكل طفل تضم

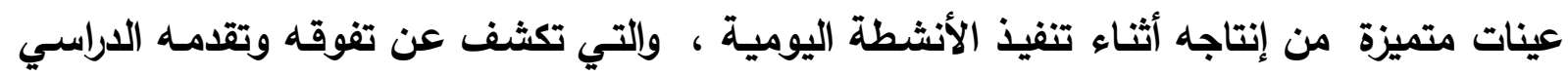

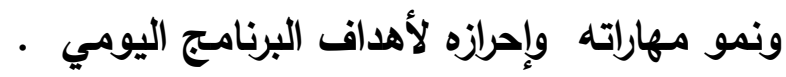

ץ - يثارك الطفل المعلمة في اختيار نماذج من إنتاجه ونشاطه اليومي المميز ،لوضعها في الحقيبة

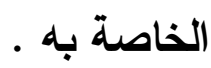

r - تعتمد أسـاليب تقيـيم البورتفوليو عل إستراتيجية التقويم التكويني ، ويكون مصـاحب لعمليـة التدريس وبعد الانتهاء منها مباشرة للوقوف علي مدي تحقق الأهداف السلوكية المحددة من قبل . 
ع - تقوم المعلمة بوضـع تقديرا لكل عمل ينتجه الطفل أثناء تـريس الأنثطة المتنوعـة ، وكتابـة

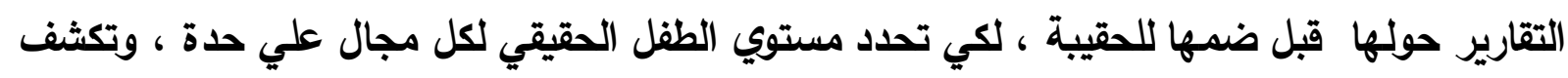

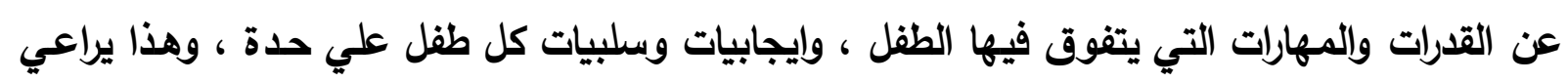
الفروق الفردية بين الأطفال .

ه - في ضوء نتائج الطفل وانجازاته وعينات العمل والموجودة بحقيبة الطفل تقارن بين أدائه الحالي

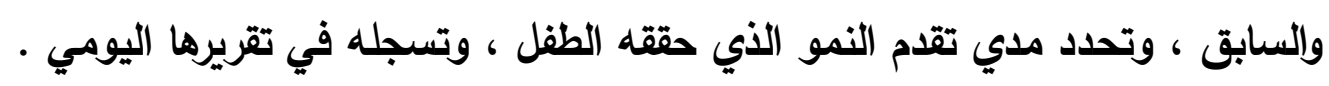
4 - تحدد إستراتيجية خاصـة للتعامل مـع كل طفل لتعديل السلوكيات السلبية والتأكيد علي الجوانب

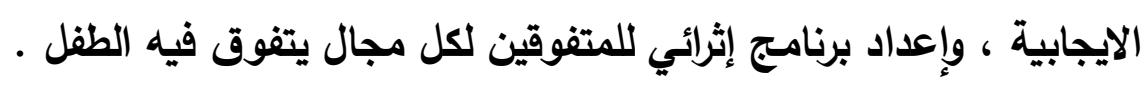

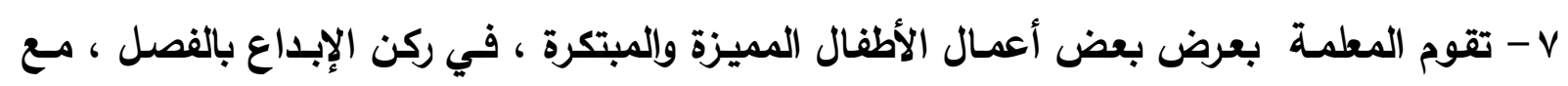

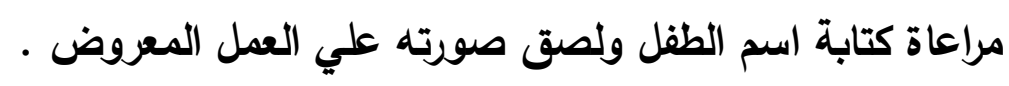
1 - دعوة أولياء الأمور لزيارة الروضة واطلاعه علي حقيبة طفله والأعمال المميزة المعروضة بركن الابتكار.

9 - توجيه الآباء لمعاملة طفله المميز وتوفير البيئة المثيرة والمشجعة علي الإباع والابتكار ، وتوفير الألعاب والأنشطة التي تتفق مع ميوله وقدراته ودفع وتثجيع الطفل علي الانجاز والإبداع . • 1 - المجموعة الضـابطة تدرس نفس الأنثطة والخبرات التي تدرسـها التجريبية ولكن بالطريقـة العادية .

ثالثنا : بـعـد التجربــة : قام الباحث بتطبيق اختبار التفكير ألابتكاري لكـلآ المجموعتين التجريبية والضابطة .

رابـعا: متابـعة التجربـة : ق قام الباحث بوضع برنـامج زيارات أسبوعية ، بمعدل يـوم في الأسبوع

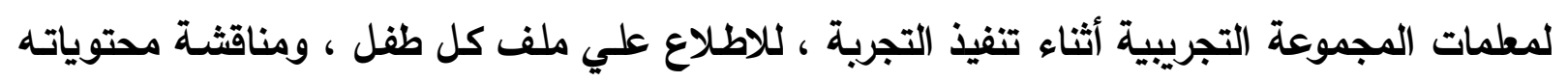

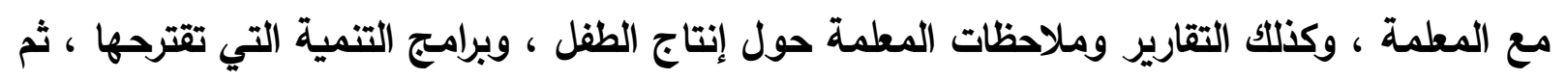

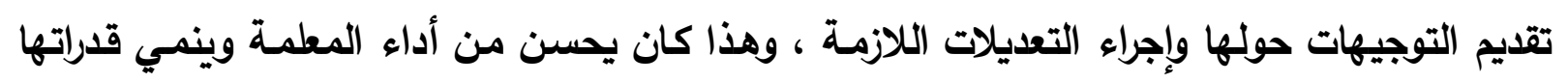

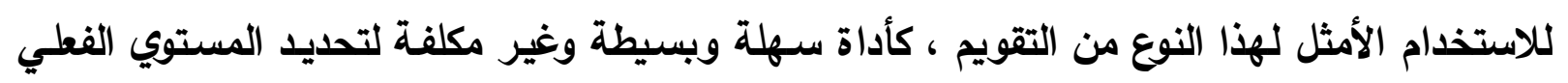

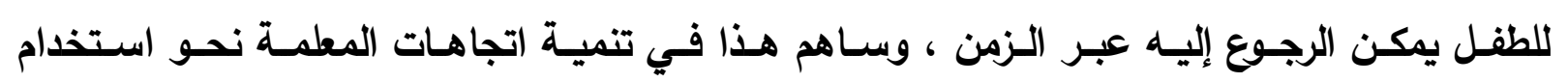
الإستراتيجية في تقويم الأطفال ـ والتي كانت مشوقة ويتجاوب الأطفال معها وتدفعهم للبحث والتفكير. 


\section{نـنائم الدراسة ومنـاقَتْنها :}

أولا : النتنائج المتهعلقة بالفرض الأول :

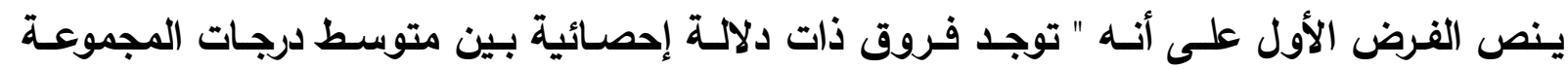

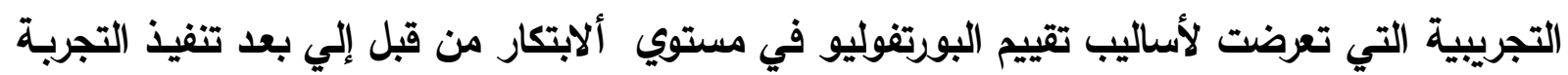
لصالح التطبيق ألبعدي ". • دلالدة تأثير برنامج تقييم البورتفوليو علي التفكير ألابتكاري لاي المجموعة التجريبية من

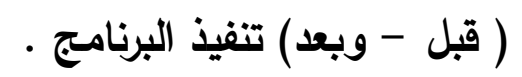

ويوضح الجدول رقم (r) ذلك .

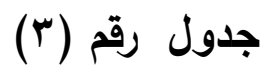

نتائج اختبار (ت) لالالة التحسن من متوسطي أداء المجموعة التجريبية علي مقياس تور نس الاسك للتفكير ألابتكاري من من قبل - بعد) تنفيذ التجربة.

\begin{tabular}{|c|c|c|c|c|c|c|c|}
\hline الدلالة & נ.د & ت & مج حץف & م ف & المقياس & $\dot{ن}$ & العينة \\
\hline دالة عذد مستوي ا • و & 10 & هو 9 & q. & لوو 0 & \multirow{3}{*}{ الطلاقة الأصالة } & \multirow[t]{3}{*}{17} & \multirow[t]{3}{*}{ بنون ب } \\
\hline دالة عذد مستوي ا · و & 10 & $1.0 \mathrm{~V}$ & rq & ل ل & & & \\
\hline دالة عذ مستوي ا.و & 10 & agr & $1 \leq \cdot 904$ & اوv & & & \\
\hline دالة عذ مستوي 1 .و & 10 & $r \cdot r$ & 101997 & & الكلي & 17 & \\
\hline دالة عند مستوي ا.و & ir & لاو 1 ل ل & צות & rو & الطلاقة & $1 \varepsilon$ & بنات بن \\
\hline
\end{tabular}




\begin{tabular}{|c|c|c|c|c|c|c|}
\hline دالة عند مستوي ا · و & ir & عو & צ' & \&.Y & \multirow{2}{*}{ الأصالة } & \\
\hline دالة عند مستوي ا لو & 14 & $\Lambda$ & E E & عو 7 & & \\
\hline دالة عند مستوي ا • و & 14 & او 17 & IVOg0 & 10و 10 & الكلي & $1 \leq$ \\
\hline
\end{tabular}

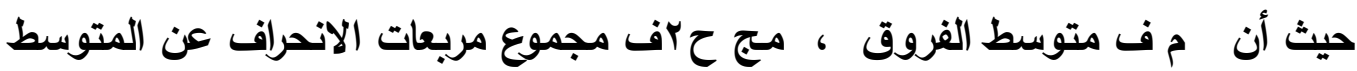

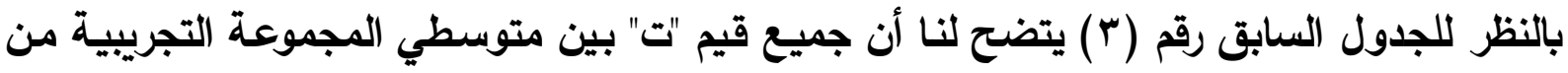

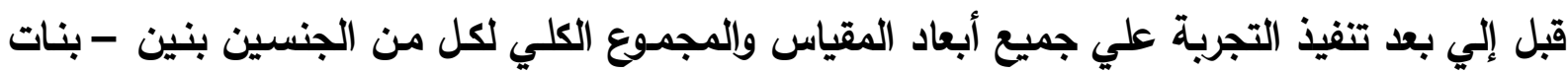

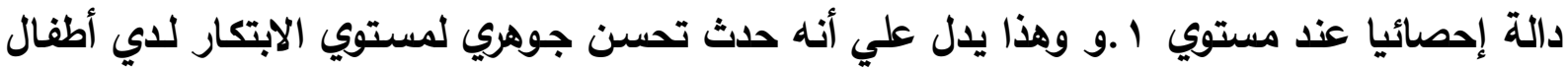
المجموعة التجريبية بعد تعرضهم لأساليب تقييم البورتفوليو ، مما يؤكد فعالية هذه الأساليب ، وأنها

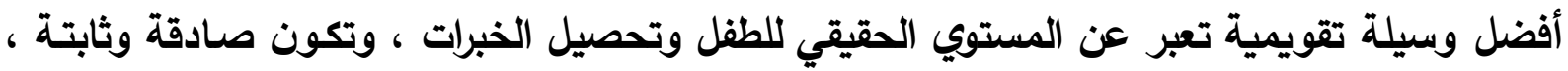
وموثقة للتعلم عبر الزمن ، لا تقف عند حد التشخيص فقط بل يتبعها إجراءات عملية واقتراح الحلول

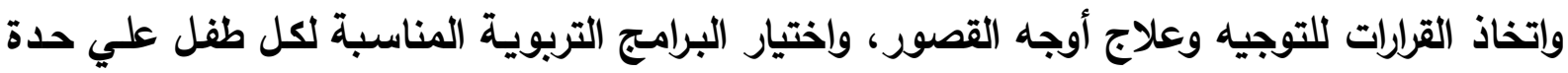

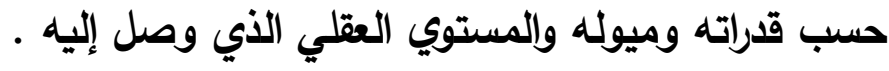

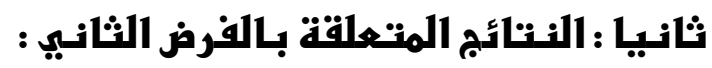

ينص الفرض الثاني علي أنـه "لا توجد فروق ذات دلالـة إحصائية بين متوسط درجات المجموعة الضابطة في مستوي الابتكار بين التطبيقين القبلي والبعدى ".

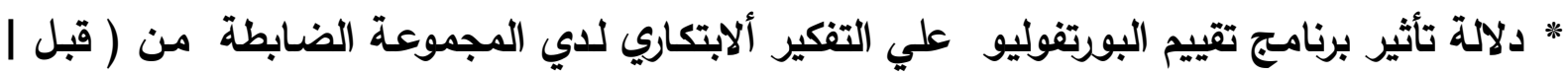

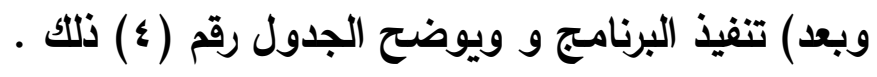

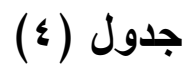

نتائج اختبارات (ت) لدلالة التحسن بين متوسطي أداء المجموعة الضابطة علي مقياس التفكير ألابتكاري

من ( قبل /بعد) تنفيذ التجربة.

\begin{tabular}{|c|c|c|c|c|c|c|c|}
\hline الالالة & د. & ت & ف & م ف & أبعاد & $\dot{~ ن}$ & العينة \\
\hline دالة عند مستوي ا. و & 10 & $v_{9}$ & ك97 & اوا & الطلاقة & \multirow[t]{3}{*}{17} & \multirow[t]{3}{*}{ بنون } \\
\hline دالة عند مستوي ا. و & 10 & 11 & r99 & اوا & الأصالة & & \\
\hline دالة عذ مستوي ا.و & 10 & V & 999 & عو 1 & التخيل & & \\
\hline دالة عذد مستوي 1 .و. & 10 & ᄉ & اوبrع & ل ل & الارجة الكلية & 17 & بنون \\
\hline
\end{tabular}




\begin{tabular}{|c|c|c|c|c|c|c|c|}
\hline & & & & & ل للابتكار & & \\
\hline دالة عذ مستوي ا. و & ir & هو & 9 & 1.0 & الطلاقة & \multirow[t]{3}{*}{$1 \varepsilon$} & \multirow[t]{3}{*}{ بنات } \\
\hline دالة عذد مستوي ا. و & ir & 1. & T Tو r & سو ا & الأصالة & & \\
\hline دالة عند مستوي ا. و & ir & 0 & דr & rو 1 & التخيل & & \\
\hline دالة عند مستوي ا. و & 14 & $11 \mathrm{gV}$ & V r r r r & او؛ & للابتكار & $1 \leq$ & بنات \\
\hline
\end{tabular}

ويتضح لنا أيضا من الجدول رقم (ع) أن جميع قيم ت دالة أيضا إحصائيا عند مستوي 1. و لجميع أبعاد المقياس والمجموع الكلي ، لدي كل من عينة البنين والبنات وإلكلية ، وهذا يثبت عدم صحة الفرض الثاني ، وقد يرجع هذا التحسن في مستوي الابتكار للنمو العقلي الذي يسير بسرعة كبيرة في

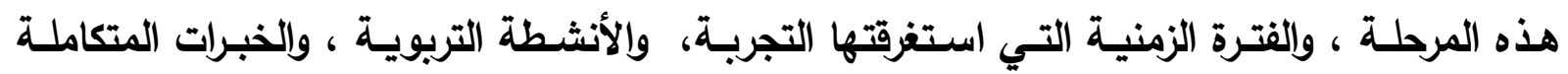
للمستوى الثاني التي تعدها المعمات المتخصصات ، والتي تعرض لها أطفال المجموعتين التجريبية والضابطة

ثالثا : النتائسج المتعلقة بالفرض الثالث يـص الفرض الثالث علـي أنـه " توجـ فروق ذات دلالـة إحصـائية بـين متوسـط درجـات أطفـال المجموعتين التجربيبة والضـابطة علي مقياس التفكير ألابتكاري مـن قبل إلـي بعد تنفيذ التجربـة لصالح التجريبية التي تعرضت لأساليب تقييم البورتفوليو" . البانب الآول : دلالة تأثير برنامج تقييم البورتفوليو علي التفكير ألابتكاري لاي المجموعتين التجريبية والضابطة من ( قبل/ بعد) تنفيذ البرنامج و ويوضح الجدول رقم (0) ذلك . جدول رقم)(0)

نتائج اختبار (ت) لدلالة الفرق بين متوسطي الارتفاع في أداء كل من المجموعتين التجريبية والضابطة من قبل إلي بعد تنفيذ التجربة علي مقياس التفكير ألابتكاري.

\begin{tabular}{|c|c|c|c|c|c|c|c|c|c|}
\hline \multirow{2}{*}{ الدلالة } & \multirow{2}{*}{ د } & \multirow{2}{*}{ ت } & \multicolumn{2}{|c|}{ الضابطة } & \multicolumn{2}{|c|}{ التجربيية } & \multirow{2}{*}{ المقياس } & \multirow{2}{*}{$\dot{~}$} & \multirow{2}{*}{ العينة } \\
\hline & & & ع ف & م ف & ع ف & م ف & & & \\
\hline دالة عن مستوي ا.و & & V V & 7و. & اوا & كو r & لو ه & الطلاقة & 1 & بنون \\
\hline دالة عند مستوي ا.و & $r$. & ل Vوr & ؛و. & اوا & rو & Vو & الأصالة & 7 & \\
\hline دالة عذد مستوي ا.و & & זوه & ل او. & ع وا & $r$ & اوV & التخيل & & \\
\hline
\end{tabular}




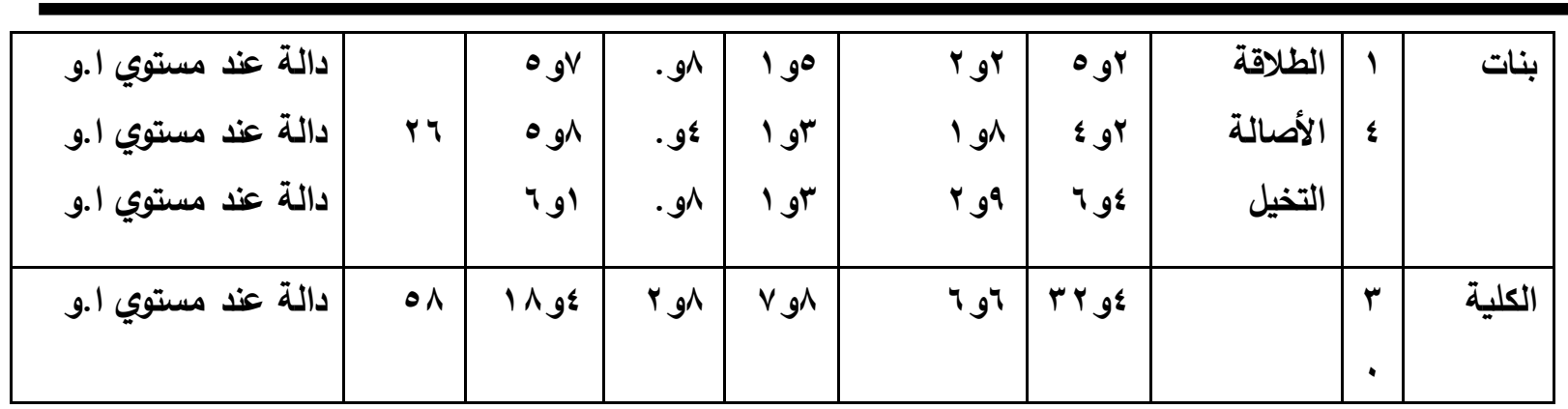

حيث أن م ف متوسط الفروق ، ع ف الانحراف المعياري للفروق ، د.ح درجة الحرية

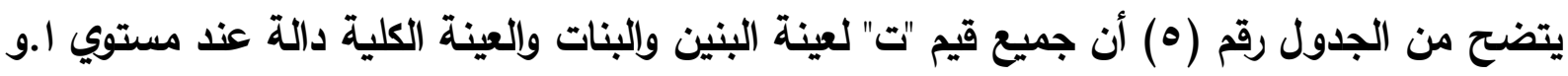

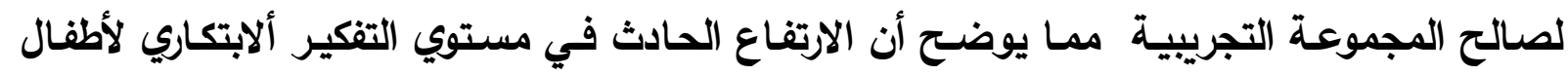

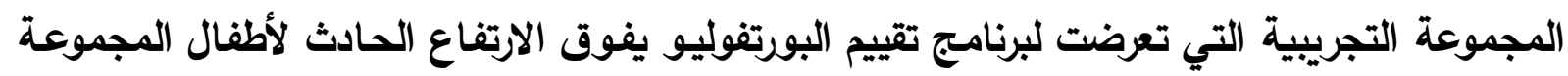

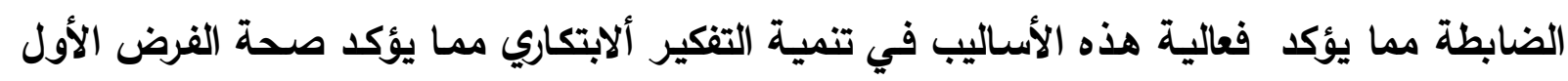

الجانب الثاني : مدي التحسن من الممكن تقدير حجم التحسن الحادث في مستوي التفكير ألابتكاري للمجموعتين التجريبية والضابطة

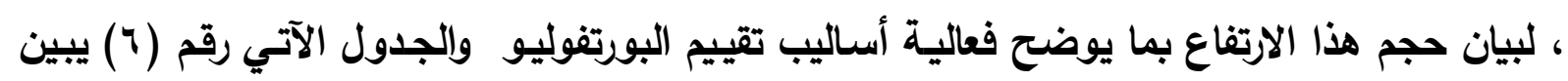
ذلك
جدول رقم (7)

يوضح حجم تأثير أساليب تقييم البورتفوليو علي التحسن في أداء أفراد العينة علي مقياس التفكير ألابتكاري.

\begin{tabular}{|c|c|c|c|c|c|c|}
\hline 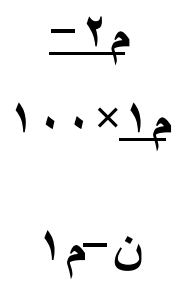 & $\begin{array}{c}1 \cdots \times \mu_{p}-r_{p} \\
1_{p}\end{array}$ & $\begin{array}{c}\ldots \\
1 \ldots \\
\dot{0}\end{array}$ & p & م 1 & النهاية & المجموعة \\
\hline$\% r \varepsilon$ & $\%$ । O & $\%$ r & عو rr & אو r & $9 \varepsilon$ & التجريبية \\
\hline \%^و & مو & r r vو & هو 19 & זو r & $9 \leq$ & الضابطة \\
\hline
\end{tabular}




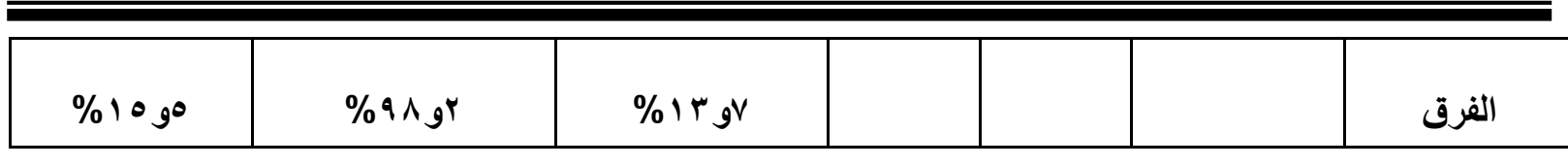

م متوسط القبلي ، مج متوسط البعدي ن النهاية العظى للاختبار

يتضـح من الجدول السـابق وجود فروق كبيرة في حالات الكسب المعدل الثلاث للدي المجموعتين

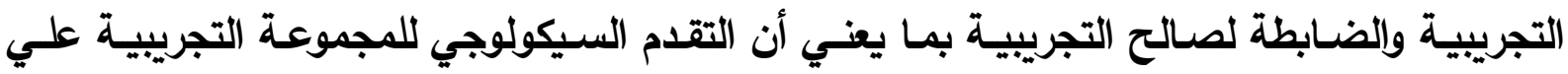

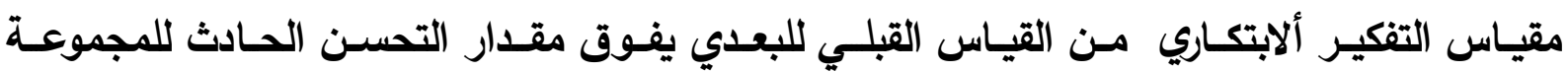

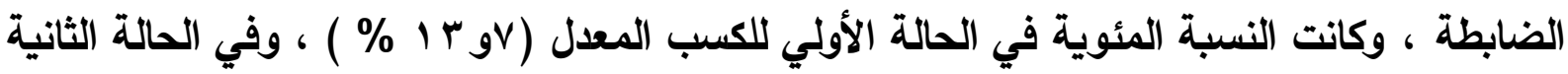

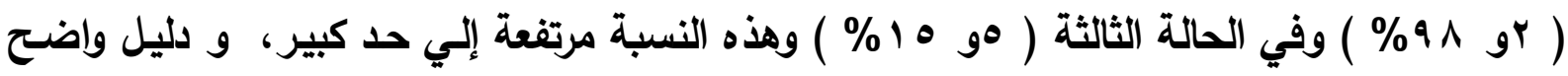
علي أن أساليب تقييم البورتفوليو كان لها أثرا فعالا في تحسين مستوي التفكير ألابتكاري للأطفال وهذه وهذه

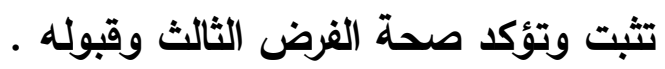

مناقشة النتائج :

لقد أوضحت الاراسة فعالية استخدام تقييم البورتفوليو في تنمية الابتكار لدي أطفال الروضة ، وهذا

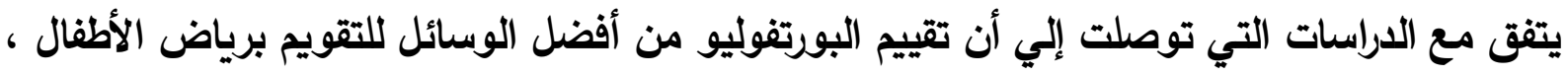

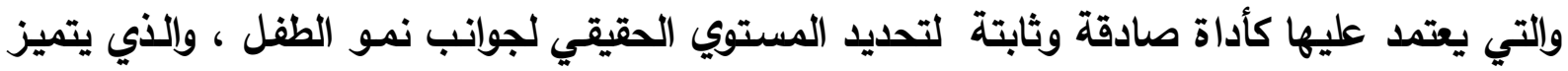

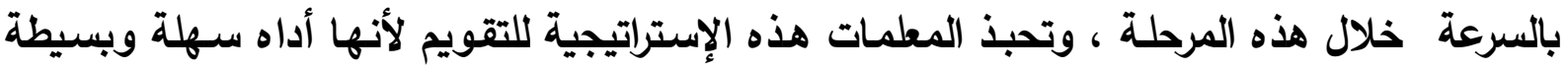

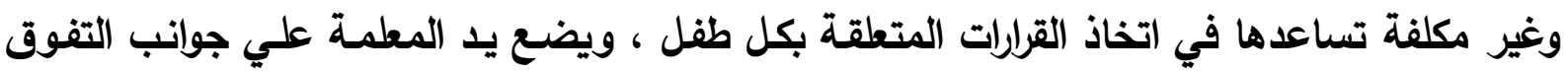
وإلنبوغ ، وتشخيص نقاط القوة والضفف عند كل طفل علي حدة ، من خلال فحص ملف الطفل الذي

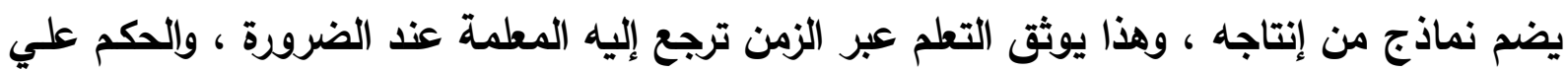

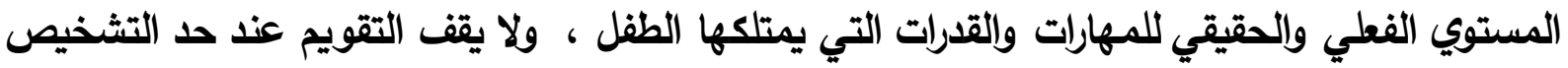

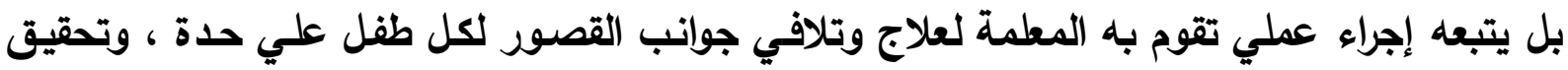

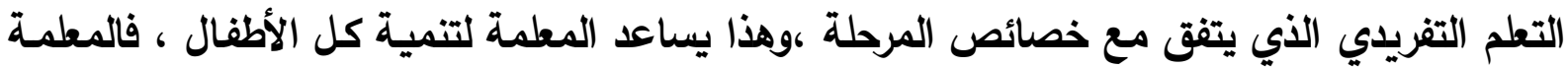
تعد برامج وأنشطة مناسبة للطفل الضعيف والمتوسط ، وأيضا تهتم بالمتفوقين من خلال إعداد برامج إثرائيه تتحدي قدراتهم وتدفعهم للبحث والتفكير ، والذي يحقق مستوي نمو مرتفع للطفل ، وهذه النتائج

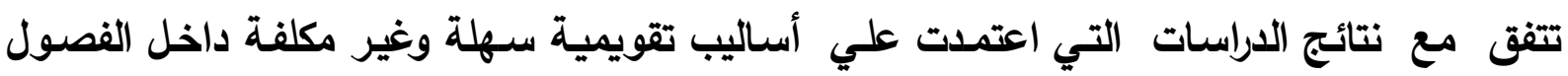

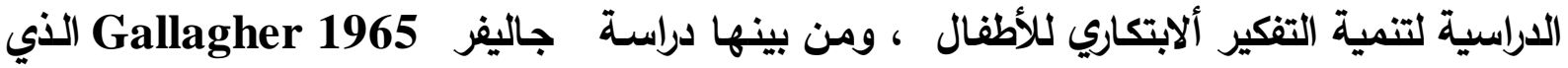
توصل إلى أن نوعية الأسئلة التي تتضمن المستويات المعرفية العالية والتي يطرحها المعلم داخل ولئل

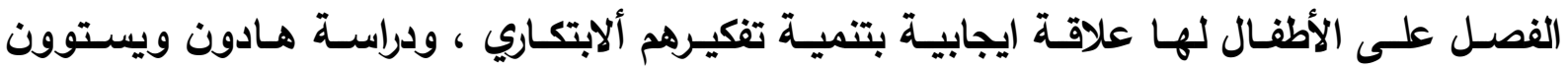




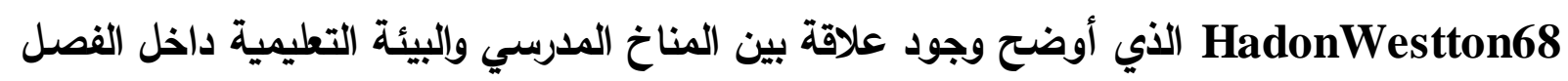

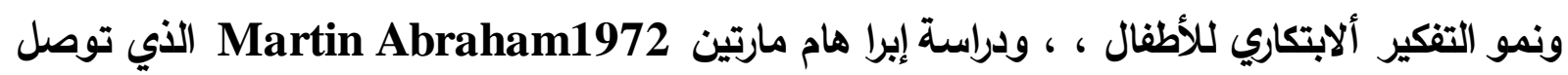
لوجود علاقة بين نوعية الأسئلة التي تطرح داخل الفصل ودرايدة إيرام مارئ ونمو التفكير ، وفي دراسـة ميشيل برين

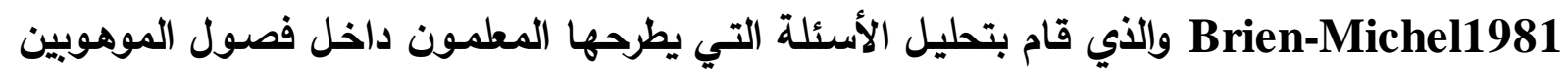

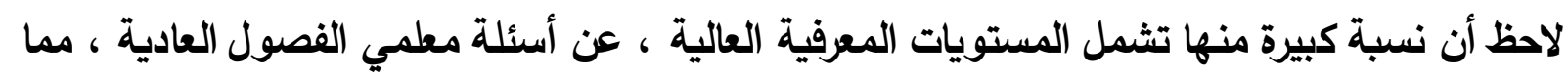

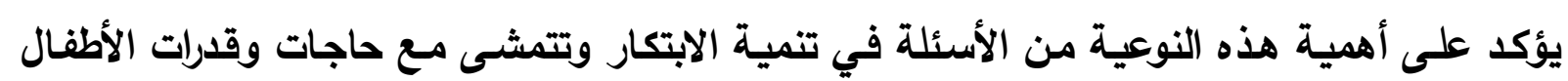

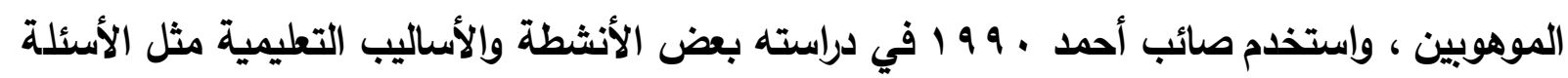

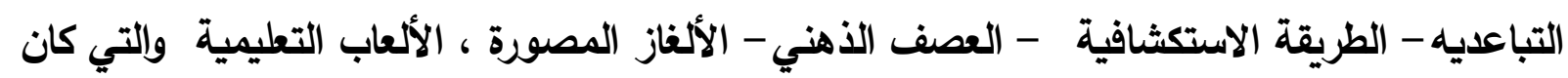

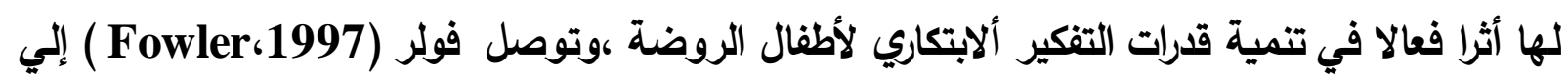

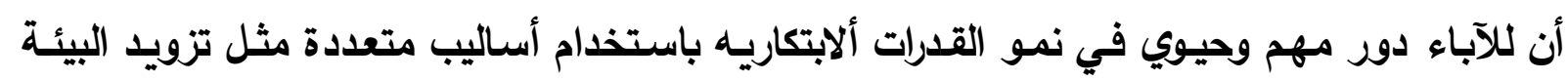

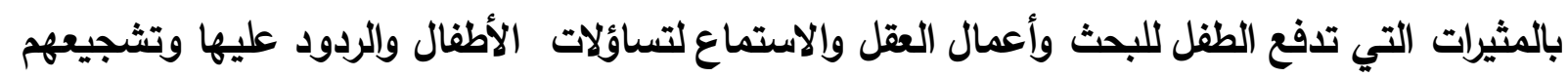

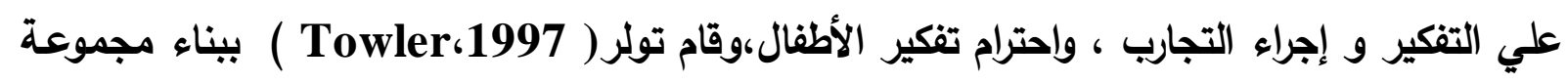

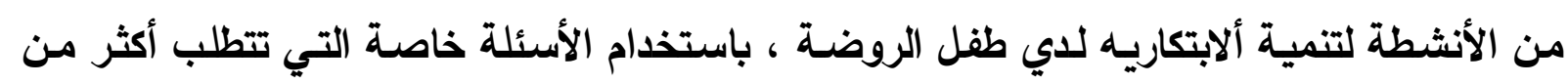

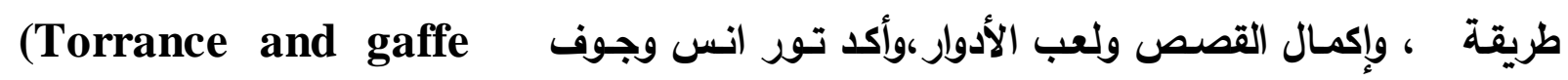
(1990.علي أهمية دور المعلمات في تنمية التفكير ألابتكاري للأطفال عن طريق الاهتمام بالأسئلة

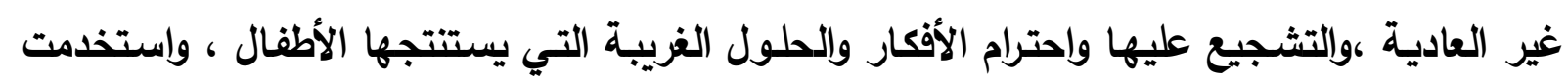

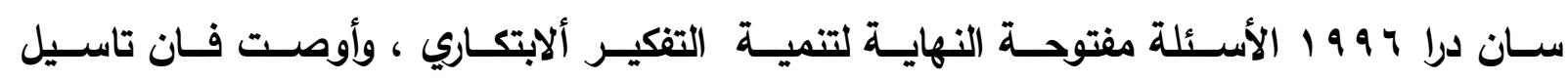

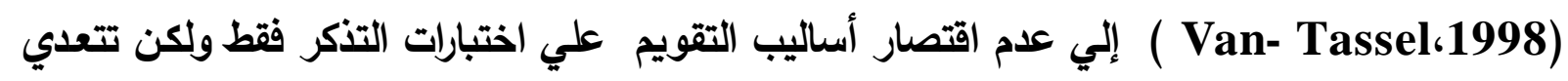

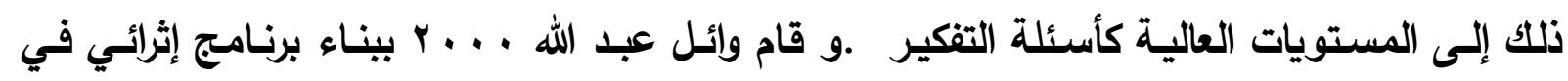

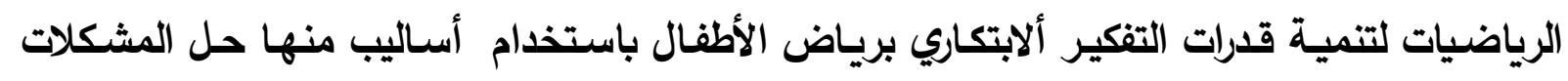

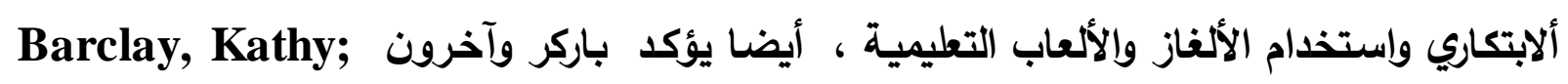
Breheny，Camille (1994)

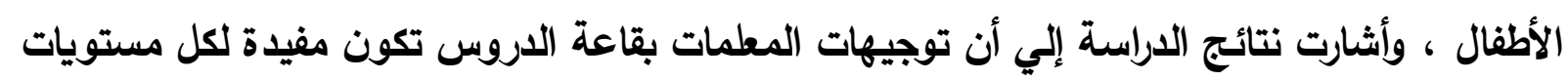

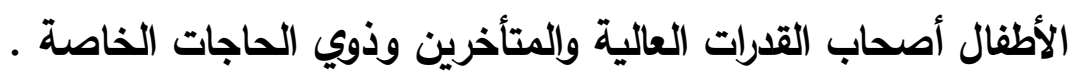

ثانيا : التوصيات :

في ضوء نتائج الدراسة فإن الباحث يوصى بما يلي : 1- في مجال استخدام حقيبة التقييم :

• توضيح الأثياء التي نجمعها في الحقيبة للأطفال . 


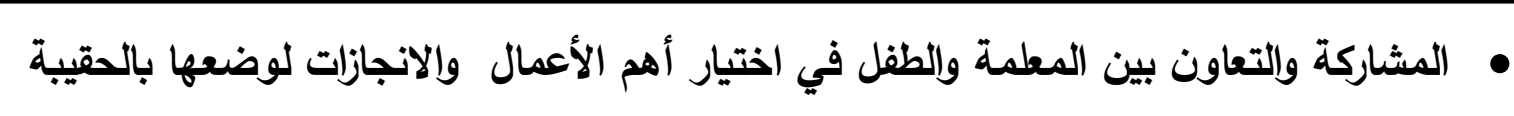

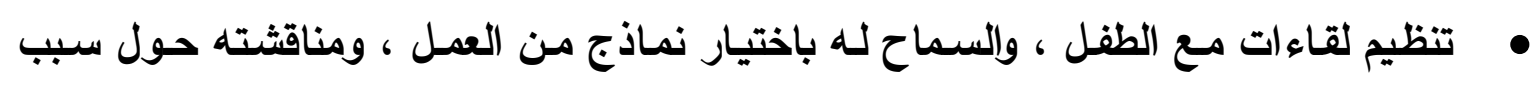

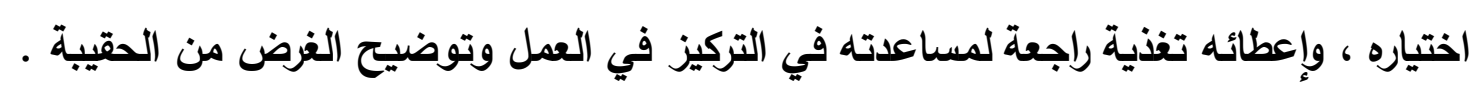

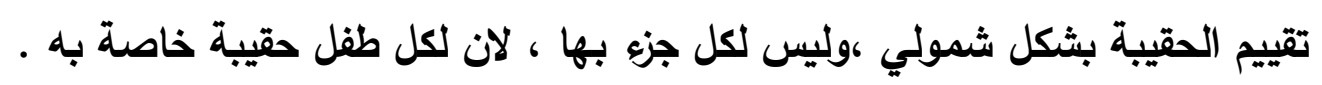

r - أن يحتل التقويم مكانة هامة في برامج إعداد وتدريب معلمات الروضة كمدخل أساسي لتطوير التعليم رياض الأطفال.

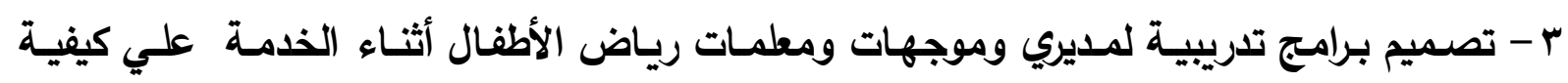

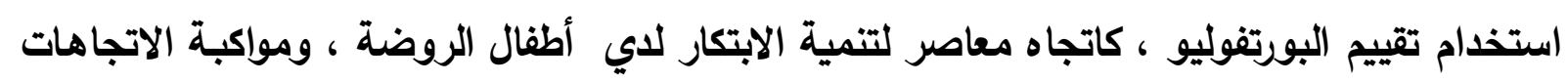
العالمية في هذا الاتجاه

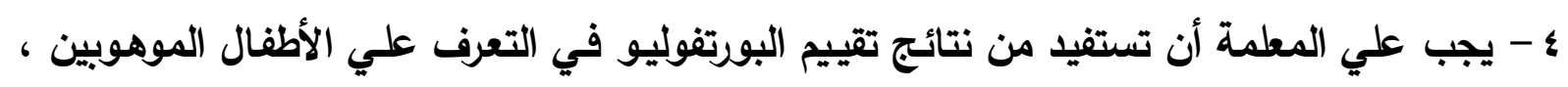

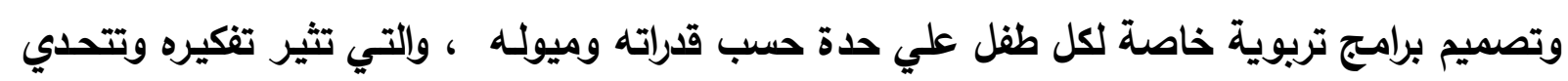

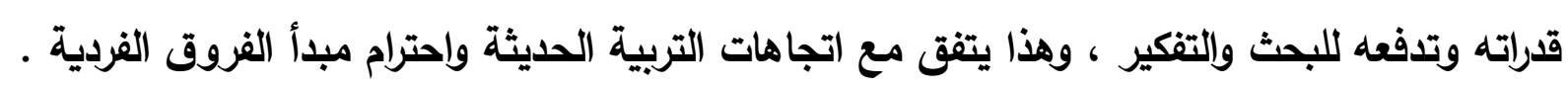

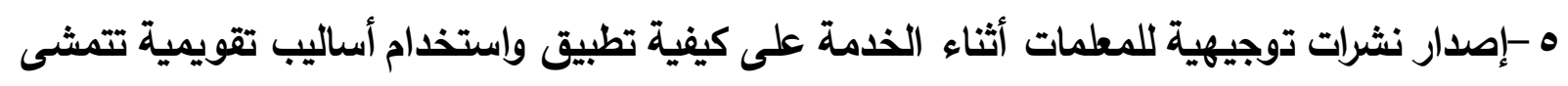
مع قدرات أطفال الروضة. 


\section{ملفم الدرواستة}

بعنوان " استخدام تقييم البورتفوليو " Portfolio " لتنمية الابتكار لاي أطفال الروضة "

\section{إعداد د/ محمد كمال يوسف}

تهدف الدراسة إلي استخدام أسلوب تقييم البورتفوليو، كأداة مناسبة لتحديد مستوي نمو الأطفال ،

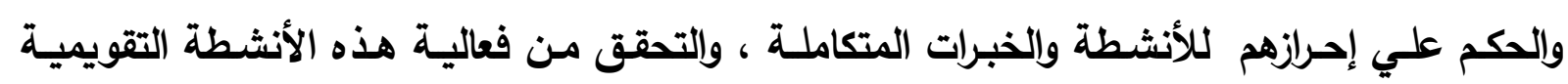
والأساليب في تنمية الابتكار لاي أطفال الروضة. وتكونت عينة الدراسة من ( • بطفل وطفلة ) تم اختيارها عشوائيا من بين الملحقين بالمستوي الثاني

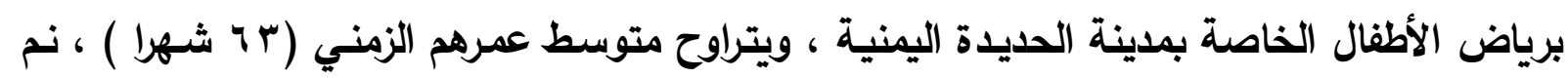

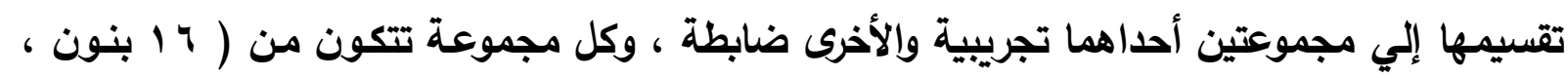
ع أبنات ). واستندم في الدراسة الأدوات الآتنية : 1 - اختبار رسم الرجل لجودا نف ها ريس لقياس الأكاء (تقنين فاطمة حنفي ، 91 1 ). ץ - مقياس المستوى الاجتماعي الاقتصادي للأسرة (إعداد عبد العزيز الثخص ، 999 1).

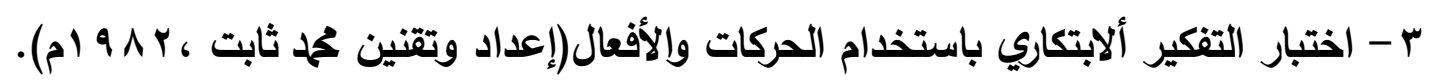
؛ - أساليب تقييم البورتفوليو " حقيبة الطفل " (إعداد الباحث ) . 
وتوصلت ننائج الدراسة أن أساليب تقييم البورتفوليو كان لها أثرا فعالا في تحسين مستوي ألابتكار لدي

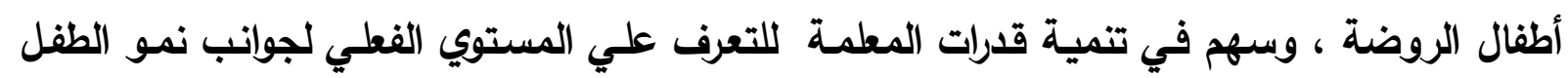

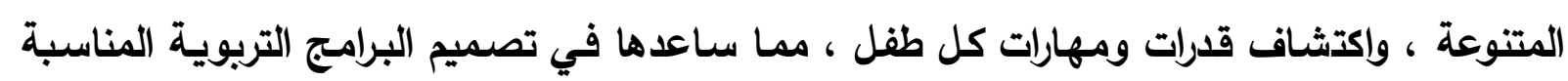

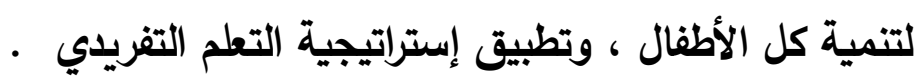

المراجع

أولا : المراجع العربية :

1 - الكسندرو رو شكا: " الإبـاع العام والخـاص" ترجمـة غسـان عبد الحي ،الكويت ، عـالم

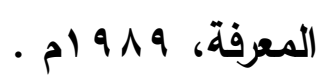

r - ايفال ـ عيسي: مدخل الي التعليم في الطفولة المبكرة : ترجمة أحمد حسين الثافعي ، دار

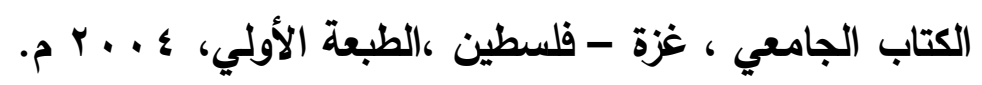

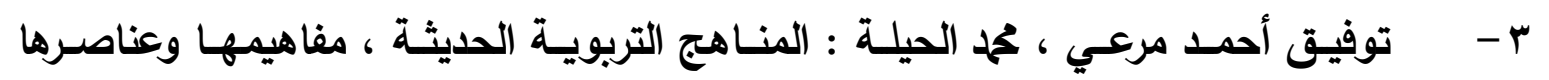

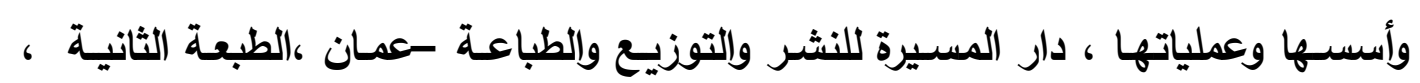
م. 1

؛ - جابر عبد الحميد جابر : اتجاهات وتجارب معاصرة في تقويم أداء التلميذ والمدرس ،

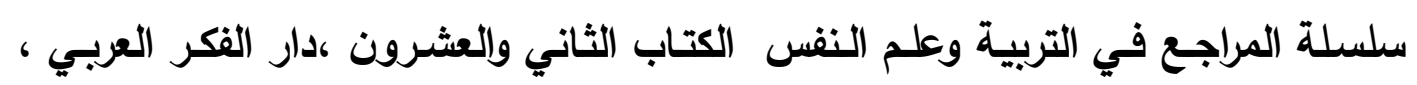

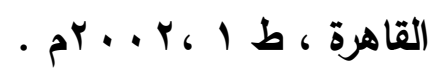
ه - حسن شحاتة: ( ثقافة الذاكرة وثقافة الإبداع وعلاقتهما بكتب اللغة العربية في الحلقة

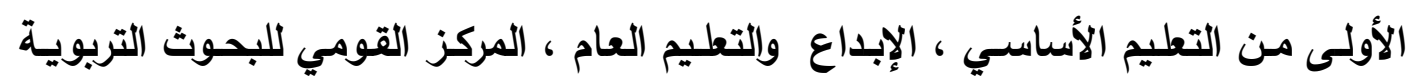

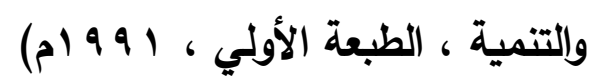

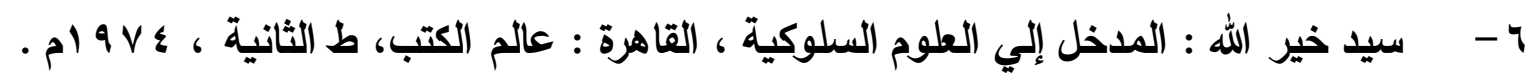

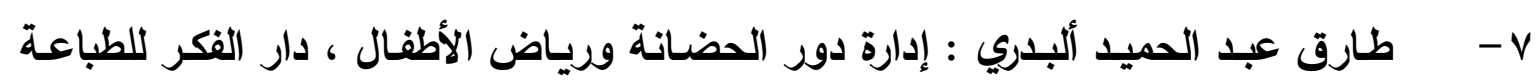

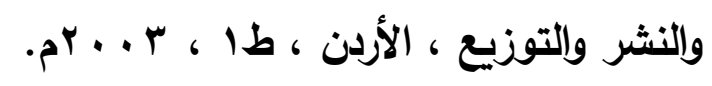


1 - عادل عبد الله عحم : رعاية الموهوبين ، إرشادات للآباء والمعمين ،القاهرة ، دار الرشاد ،

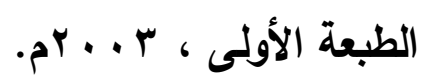

9- - عبد الرحمن سيد سليمان ، صفاء غازي أحمد : المتفوقون عقليا ، خصائصهم - اكتشافهم

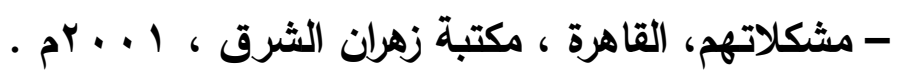

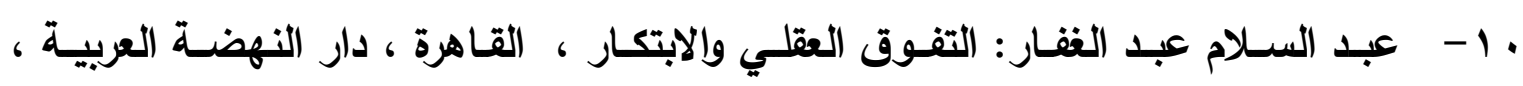

$$
\text { . } 199 \mathrm{~V}
$$

1 - عزيزة اليتيم : الأسلوب الإبداعي في تعليم طفل مـا قبل المدرسـة ، أسسـه ، مهاراته ،

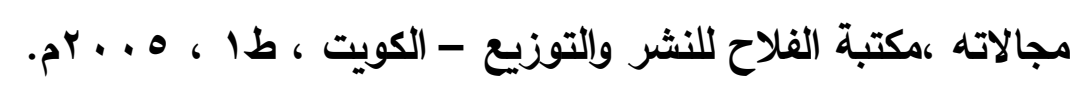

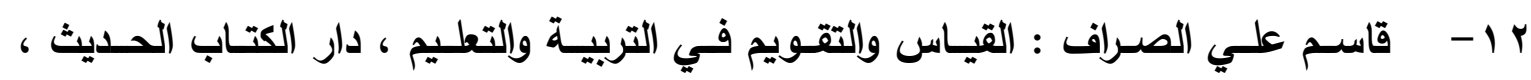

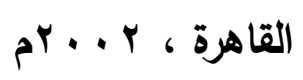

r ا - عحم عبد الرحيم عدس : مدخل إلي رياض الأطفال ،دار الفكر للطباعة والنشر والتوزيع -

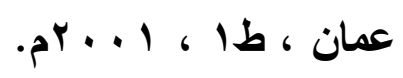

ء ا - هدي محمود الناشف : تصميم البرامج التعليمية لأطفال ما قبل المدرسـة ، دار الكتاب

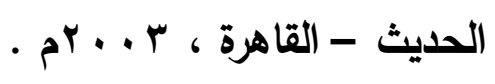

ه - هند ماجد الخثيلة : إدارة رياض الأطفال ، دار الكتاب الجامعي - العين - الإمارات العربية

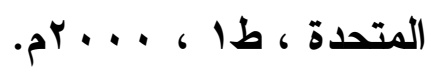

\section{ثانيا : المراجع الأجنبية :}

16- Arter, J .And Spandel, V: A Using Portfolios of Student Work in Instruction and Assessment, Education Measurement, Issues and Practice , 11, 1, pp36-44, 1992.

17- Barclay, Kathy; Brea hinny, Camille: Hey, Look Me Over Assess, Evaluate and Conference with Confidence, Childhood Education, v70 n4 p215-20 Sum 1994.

18 - Barclay, Kathy; Breheny, Camille: Dimensions of Early Childhood, v22 n2 p40-41 Win 1994.

19-Balm, Sally St. Mary: Using Portfolio Assessment in a Kindergarten Classroom, Teaching and Change, v2 n2 p141-51 Win 1995 
20- Blenkin and Kelly : Early Childhood Education A Developmental Curriculum ", Second Edition ,Paul Chapman Publishing Ltd ,London ,UK, , 1996.

21- Bowden, Shelly Hudson: Literacy All the Livelong Day: A Picture Portfolio of Kindergarten Teaching and Learning, Language Arts, v82 n4 p278 Mar 2005

22-Bredecamp, \& Shepard, : how best to protect children from in appropriate school expectations, practices. Young children ,44(3) pp 19-24. 1989.

23- Diffily, Deborah; Fleege, Pamela :The Power of Portfolios for Communicating with Families.

24 - Dodge and Colker, L: "The Creative Curriculum For Early Childhood "Third Edition , Teaching Strategies,2000.

25- Gallagher ,J, :Expressive thought by gifted children in the classroom, Elementary English , 42, 5, 559, 1965. From ( Education Research , 20 ,2 , pp 102- $103,1978$.

26 - Hodges, V. Pauline: Teaching Writing to At-Risk Students in a Rural High School, , Rural Educator, v16 n2 p28-31 Win 1994-95

27- Hall, Bruce W.; Hewitt-Gervais, Cynthia :The Application of Student Portfolios in Primary-Intermediate and Self-Contained-Multiage Team Classroom Applied Measurement in Education, v13 n2 p209-28, 2000

28- Hendric $s, \mathbf{j}$ : total learning curriculum for the young child, (2nd ed ).Columbus oh , Merrill publishing . 1986.

29 - Kankaanranta, Maria: Constructing Digital Portfolios: Teachers Evolving Capabilities $i \mathrm{n}$ the Use of Information and Communications $\begin{array}{llllll}\text { Technology Teacher Development, v5 } & \text { n2 } & \text { p259-75 } & 2001\end{array}$

30 - Kubota ,- Mikio : Question answer behavior in esi and EFL Classrooms, similarities and differences, $p$ 48, master research paper Georget own University 
31 - Meisels, Samuel J.; And Others: The Work Sampling System: Reliability and Validity of a Performance Assessment for Young Children,: Early Childhood Research Quarterly, v10 n3 p277-96 Sep 1995

32- Niikko, Anneli : How Do Kindergarten Teachers Evaluate Their Portfolio Working Process? International Journal of Early Years Education, v10 n1 p61-74 Mar 2002

33 - Warner, Laverne; Adams, Polly: Teachers as Action Researchers in the Classroom, Dimensions of Early Childhood, v24 n1 p22-25 Win,1996

34- worth am: tests and measurement in early childhood education Columbus oh: Merrill publishing . co, ,(1990). 